\title{
Green Concrete for a Circular Economy: A Review on Sustainability, Durability, and Structural Properties
}

\author{
Abathar Al-Hamrani ${ }^{1}$, Murat Kucukvar ${ }^{2, *} \mathbb{B}$, Wael Alnahhal ${ }^{1}\left(\mathbb{D}\right.$, Elsadig Mahdi ${ }^{2}{ }^{\mathbb{D}}$ and Nuri C. Onat ${ }^{3}$ \\ 1 Department of Civil and Architectural Engineering, Qatar University, Doha 2713, Qatar; \\ aa1205725@student.qu.edu.qa (A.A.-H.); wael.alnahhal@qu.edu.qa (W.A.) \\ 2 Department of Mechanical and Industrial Engineering, College of Engineering, Qatar University, \\ Doha 2713, Qatar; elsadigms@qu.edu.qa \\ 3 Qatar Transportation and Traffic Safety Center, Qatar University, Doha 2713, Qatar; onat@qu.edu.qa \\ * Correspondence: mkucukvar@qu.edu.qa; Tel.: +974-4403-4332
}

Citation: Al-Hamrani, A.; Kucukvar, M.; Alnahhal, W.; Mahdi, E.; Onat, N.C. Green Concrete for a Circular Economy: A Review on Sustainability, Durability, and Structural Properties. Materials 2021, 14, 351

https://doi.org/10.3390/ma14020351

Received: 24 December 2020

Accepted: 5 January 2021

Published: 12 January 2021

Publisher's Note: MDPI stays neutral with regard to jurisdictional clai$\mathrm{ms}$ in published maps and institutional affiliations.

Copyright: (C) 2021 by the authors. Licensee MDPI, Basel, Switzerland. This article is an open access article distributed under the terms and conditions of the Creative Commons Attribution (CC BY) license (https:// creativecommons.org/licenses/by/ $4.0 /)$.

\begin{abstract}
A primary concern of conventional Portland cement concrete (PCC) is associated with the massive amount of global cement and natural coarse aggregates (NCA) consumption, which causes depletion of natural resources on the one hand and ecological problems on the other. As a result, the concept of green concrete (GC), by replacing cement with supplementary cementitious materials (SCMs) such as ground granulated blast furnace slag (GGBFS), fly ash (FA), silica fume (SF), and metakaolin (MK), or replacing NCA with recycled coarse aggregates, can play an essential role in addressing the environmental threat of PCC. Currently, there is a growing body of literature that emphasizes the importance of implementing GC in concrete applications. Therefore, this paper has conducted a systematic literature review through the peer-reviewed literature database Scopus. A total of 114 papers were reviewed that cover the following areas: (1) sustainability benefits of GC, (2) mechanical behavior of GC in terms of compressive strength, (3) durability properties of GC under several environmental exposures, (4) structural performance of GC in large-scale reinforced beams under shear and flexure, and (5) analytical investigation that compares the GC shear capacities of previously tested beams with major design codes and proposed models. Based on this review, the reader will be able to select the optimum replacement level of cement with one of the SCMs to achieve a certain concrete strength range that would suit a certain concrete application. Also, the analysis of durability performance revealed that the addition of SCMs is not recommended in concrete exposed to a higher temperature than $400{ }^{\circ} \mathrm{C}$. Moreover, combining GGBFS with FA in a concrete mix was noticed to be superior to PCC in terms of long-term resistance to sulfate attack. The single most striking observation to emerge from the data comparison of the experimentally tested beams with the available concrete shear design equations is that the beams having up to $70 \%$ of FA as a replacement to OPC or up to $100 \%$ of RCA as a replacement to NCA were conservatively predicted by the equations of Japan Society of Civil Engineers (JSCE-1997), the American Concrete Institute (ACI 318-19), and the Canadian Standards Association (CSA-A23.3-14).
\end{abstract}

Keywords: green concrete; cement; ground granulated blast furnace slag; fly ash; silica fume; metakaolin

\section{Introduction}

With the increasing risks of climate change and the depletion of natural resources due to their utilization in the construction industry, sustainability has gained wide importance and the term circular economy (CE) has emerged as one of the most important factors leading to sustainable development [1]. In contrast to the prevailing traditional economy system, which is based on a methodology of make, use, and finally, dispose of, the CE aims at continuous use of products by recycling and reusing instead of disposing to create a closed-loop system and reduce the resource consumption [2]. 
Evidence suggests that the increasing population growth rate is among the most important factors for urban expansion [3]. Recently, records have shown that compared to 1960 , at which the population was only 3 billion, the population dramatically jumped to 7.2 billion in 2017 [4]. This dramatic increase is pressing on the environment, and thus necessitates the allocation of more housing units and service and industrial facilities. As a result, countries are undergoing a revolution in terms of construction to meet the necessary needs.

From a construction perspective, the Portland cement concrete (PCC) is recognized as the most important material that is widely used in different structural applications with abundant raw material. Annually, more than six billion tons of concrete are produced globally, which are equivalent to 1 ton/capita on the planet $[5,6]$. Previous studies [5,7] reported that in a cubic yard of concrete, $10 \%$ by weight contains cement and around 0.9 tons of carbon footprint are generated per 1 ton of cement. In the manufacturing process of cement, two basic raw ingredients, namely calcareous material (i.e., limestone) and an argillaceous material (i.e., clay), are melted at high temperatures of 1400 to $1650{ }^{\circ} \mathrm{C}$, to be transferred to cement clinker [8]. Thus, this process consumes massive amounts of fossil fuels, resulting in a huge carbon footprint [5]. This is beside the carbon footprint induced by the chemical reaction involved to decompose limestone $\left(\mathrm{CaCO}_{3}\right)$ into $\left(\mathrm{CaO}+\mathrm{CO}_{2}\right)[9,10]$. The International Energy Agency (World Energy Outlook 2016) estimated the global carbon footprint to be 21.6 billion tons, of which the cement production accounts for $8 \%$ of the total carbon footprint $[9,11,12]$. Furthermore, in the last decade, the cement industry has become the second-fastest growing industry in releasing $\mathrm{CO}_{2}$ emissions due to the growing worldwide demand for concrete [7]. Meanwhile, recent statistics indicated an annual worldwide generation of slag and fly ash (FA) wastes of around 270 to 320 million tons and 1 billion tons, respectively $[13,14]$. Moreover, in the United States and Norway, the annual output of silica fume (SF) was estimated to be of the order $2 \times 10^{5}$ to $5 \times 10^{5}$ tons [15]. In Turkey, Baspinar and Demir [15] also stated that 700 to 1000 tons of SF were produced from one ferrosilicon production plant. Furthermore, the rice husk ash (RHA) is another highly reactive pozzolanic material obtained as a residue from the pod of rice grains, with a tremendous global amount of 156 million metric tons [16].

Coupled with the cement issue is the tremendous worldwide construction and demolition $(C \& D)$ wastes originated from the demolition and reconstruction of old structures, which creates another source of environmental burdens. It has previously been observed that annually, over 500 million tons of C\&D wastes are generated worldwide [17]. More recently, Akhtar and Sarmah [18] stated that a global amount of C\&D wastes exceeding 3 billion tons are generated annually, where China, India, and the USA are the major contributors to this waste. Subsequently, more land areas are being occupied and polluted when disposing C\&D wastes into landfills $[19,20]$. With this in mind, the global annual consumption of natural coarse aggregates (NCA) has reached 40 billion tons [21], and it is annually increasing by $5 \%$, whereas the highest consumption was concentrated in Asia and the Pacific [22]. This enormous consumption of non-renewable natural resources plays a vital role in depleting natural resources in several countries [23]. As a result, green concrete (GC) has been an object of research since the last century [24]. It is usually referred to as concrete that contributes toward better exploitation of waste materials, less consumption of natural resources, and less carbon footprint [5,25-30]. According to Long et al. [31], different strategies were implemented to achieve eco-friendly concrete with improved sustainability. One is reducing the depletion of natural resources by partial replacement of NCA with recycled coarse aggregate (RCA) generated from the C\&D wastes. Another approach is by partial substitution of ordinary Portland cement (OPC) with waste supplementary cementitious materials (SCMs), which were categorized according to Liew et al. [32] in three groups: 1-industrial wastes such as ground granulated blast furnace slag (GGBFS), fly ash (FA), and silica fume (SF), 2-agricultural wastes such as RHA, corncob ash (CA), and sawdust ash (SA), and 3-municipal wastes such as glass and plastics. Furthermore, cellulose nanocrystals are other green materials extracted from plants and 
trees, which when partially substituted by OPC can cause a significant reduction in $\mathrm{CO}_{2}$ consumption with improved compressive strength and fracture properties of concrete [33].

\section{Novelty and Research Objectives}

Knowing that PCC production is one of the leading causes of global warming and that there are extensive efforts worldwide to achieve a sustainable environment, this study aims to contribute to the growing research area of GC by conducting a comprehensive review on the sustainability, strength, and durability properties of GC to check for its feasibility as an eco-friendly and structural material instead of the PCC. The GC in this study will be limited to concrete that incorporates RCA as a replacement to the NCA, and either GGBFS, FA, SF, or metakaolin (MK) as a replacement to the OPC. This review paper will allow the user to select the recommended GC constituents that would suit for either lowor high-strength applications by determining the strength ranges either above or below $40 \mathrm{MPa}$ obtained from several studies available in the Scopus database at a certain age, replacement level of cement with one of the SCMs, and water binder $(\mathrm{W} / \mathrm{b})$ ratio. Also, this paper will give insights into GC performance in terms of elevated temperature, sulfate attack, chloride ion penetration, and freezing and thawing exposures. Furthermore, this study will analytically illustrate the accuracy of the available design codes and guidelines in predicting the experimental shear capacities of the previously tested GC beams. Therefore, it is intended from this review study to reach for the following:

- Discuss the sustainability benefits of GC on the environment, then provide an overview discussion of the most prominent findings concerned with the mechanical properties of GC in terms of compressive strength.

- Investigate the durability performance of GC under different harsh environmental exposures and then discuss the structural findings on shear and flexural behavior of large-scale reinforced GC beams.

- Collect all shear behavior studies that partially incorporate RCA or SCMs to replace NCA or OPC respectively, and then analytically compare their concrete shear capacities with available design codes and proposed shear equations.

\section{Literature Review}

\subsection{Review Method}

The flow chart of the review process is shown in Figure 1. Before commencing the analysis, several research papers were collected through the peer-reviewed literature database Scopus. The total number of collected papers was 1279 . The collection was done based on five search categories: (1) GGBFS concrete, (2) FA concrete, (3) SF concrete, (4) MK concrete, and (5) RCA concrete. Under each search category, a block of keywords related to either of four topics was identified, namely, the sustainability benefits, the compressive strength, the durability behavior, and the structural behavior of reinforced GC beams. As shown in Figure 1, the subcategories under these topics referred to the main points that were discussed and reviewed in the paper. The keywords' block for each search category was specified after refining author keywords or indexed keywords in Scopus. The logic operator "OR" was used to combine the different search terms in each search block. These search blocks were separately searched in the article title, abstract, and keywords search term. Under the compressive strength category, studies were only included in terms of replacing the OPC with SCMs such as GGBFS, FA, SF, and MK, whereas the RCA concrete papers were excluded. However, the RCA concrete papers were included in the remaining categories. Moreover, all non-English, numerical, and fiber-reinforced concrete articles were excluded. Based on this selection criteria and after screening papers' abstracts to check for relevant research, 114 papers were collected for this review study. 


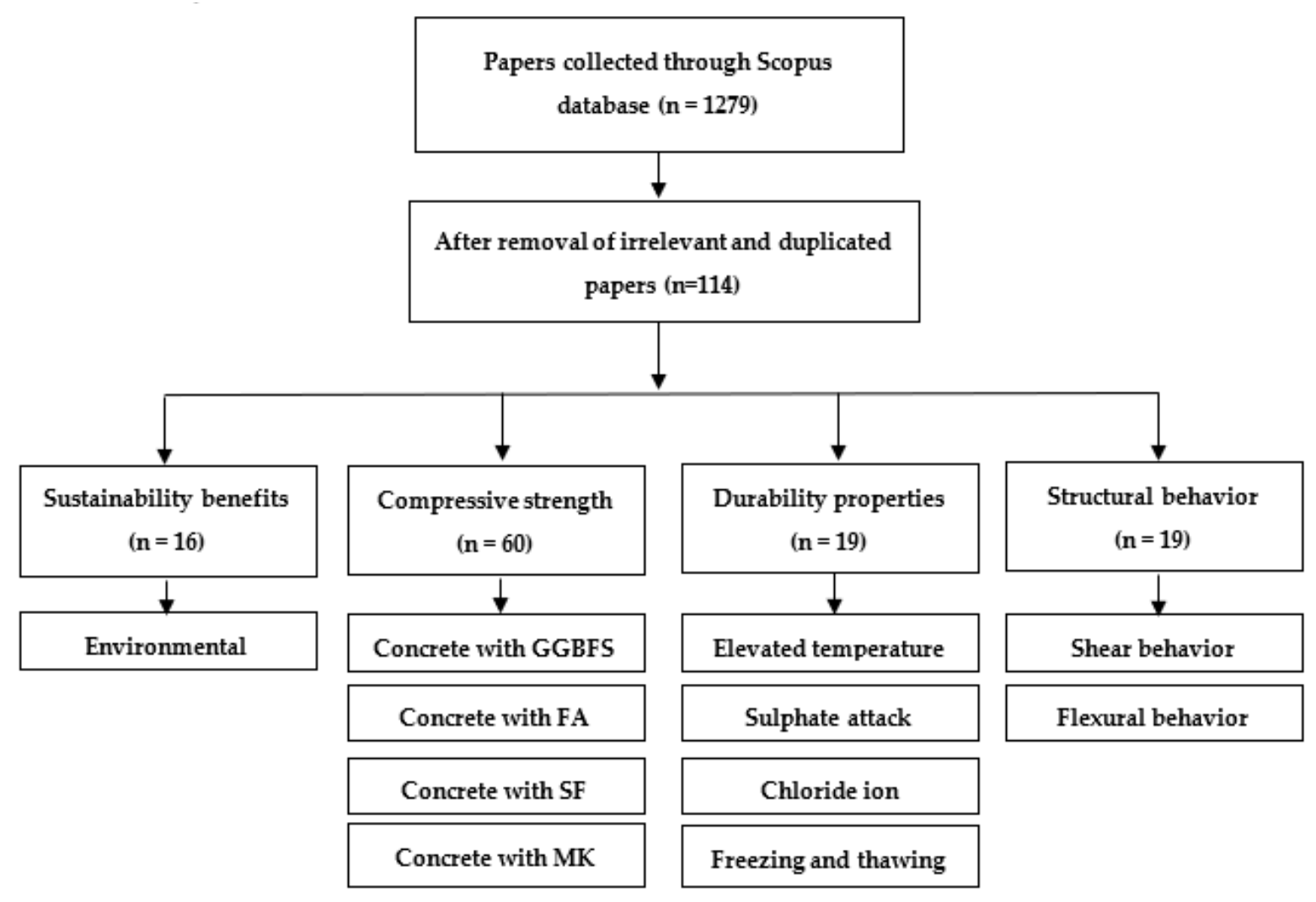

Figure 1. The process used to conduct this review.

\subsection{Sustainability Benefits of GC}

Worldwide, waste is a growing public health concern. However, recognizing it as a potential source of raw material for the industry would enhance the resource efficiency, because following such a strategy could establish a CE system, by which the materials loops will be closed. Thus, minimizing natural resources depletion, reducing carbon footprint, and eliminating wastes [6,34-36]. In the initial phase, the RC's ingredients are manufactured after supplying the factories with the recommended raw materials, and waste by-products such as GGBFS, FA, and SF to partially replace the OPC and to avoid their disposal into landfills. This is followed by the construction processes and the service life of the building. Whenever needed, the building should be refurbished and repaired to extend its lifetime. At some stage, where the building would reach the end of its life, the demolition action will take place and the generated waste could be recycled for the same or another process.

In the history of sustainable development, the GC has been thought of as a key factor in improving the three sustainability pillars: environmental, economic, and social [25]. This is due to the circularity property found in the GC technique, which will conserve cement and natural resources for NCA, such as shale, limestone, natural rocks, and clay, reduce and save landfill areas and costs, and reduce carbon footprint by reducing the cement demand, which reduces fossil fuels consumption in the cement manufacturing process [34]. Besides, utilizing GC would conserve the water storage capacity of the ground and protect the natural habitat. This is because aggregate deposits act as an underground water reservoir, and when extracted through mining processes, the ground's storage capacity will be lost. Also, the water drainage patterns will be changed because of the change in the slope of the land and vegetation [34]. Therefore, using an eco-friendly concrete, which utilizes RCA instead of NCA, or utilizes waste SCMs as one of its ingredients to partially replace cement, might have a pivotal role in creating a facility to improve the structural knowledge and maintaining a safe ecological and economical solution. Also, the issue of disposing of these 
by-products into landfills is a major environmental problem, as they contain a significant amount of leachable toxic elements, which can cause ecological harm to the water, soil, and air [13].

To date, several studies have conducted a comparative life cycle assessment (LCA) between PCC and GC. For example, Knoeri et al. [34] analyzed the LCA of 12 concrete mixes with RCA and found out that the environmental impact was mitigated by $30 \%$ compared to their counterpart conventional concretes (CC) with NCA. This mitigation was due to the avoidance of $C \& D$ wastes disposal in landfills and the recovered scrap iron from steel reinforcement. This matches well with Yazdanbakhsh et al. [37], where two environmental impact indicators of RCA including the acidification and smog formation were lower than that of NCA by $16 \%$ and $17 \%$, respectively. In addition, in their study, Yazdanbakhsh et al. [37] demonstrated a 35\% lower environmental impact induced from transporting RCA to the ready-mix plants than transporting NCA. Faleschini and Pellegrino [38] also showed that replacing NCA with electric arc furnace (EAF C) slag in concrete has decreased greenhouse gas emissions by 35\%. According to Abbas et al. [39], implementing the RCA in concrete has another advantage of reducing cost, as aggregates are obtained locally rather than being hauled from remote locations. The LCA of Shan et al. [40] was in line with previous findings, where their results have shown a significantly lower environmental load for the local RCA than the NCA imported from overseas. Turk et al. [41] prepared GC mixes from three industrial by-products, which are (1) foundry sand, (2) EAF S (which were used as manufactured aggregates), and (3) FA (which was used as a mineral admixture). Their results indicated a $25 \%$ reduction in environmental impacts in the case of $\mathrm{FA}, 15 \%$ in the case of foundry sand, and $5 \%$ to $35 \%$ in the case of EAF S. Concerning $\mathrm{CO}_{2}$ emissions, the case of EAF $S$ showed only minor improvement, while it showed a very big improvement in Eutrophication. Gursel et al. [42] investigated the global warming potential (GWP) of RHA and FA blend concrete mixes through a LCA approach. In comparison to CC, which resulted in a GWP of $544 \mathrm{~kg} \mathrm{CO}$-eq $/ \mathrm{m}^{3}$, it emerged from their analysis that the mix with $40 \%$ OPC, $40 \%$ FA, $15 \%$ RHA, and 5\% limestone flour showed the lowest GWP of $284 \mathrm{~kg}$ $\mathrm{CO}_{2}$-eq $/ \mathrm{m}^{3}$ without considerable effect on the compressive strength. This finding was also supported by Thomas [43], where an eco-friendly, economical, and durable concrete was presented with the partial replacement of OPC with RHA. While the carbon footprint from normal concrete strength mix was found by Flower and Sanjayan [44] to be 263 to $290 \mathrm{~kg} \mathrm{CO}$-eq $/ \mathrm{m}^{3}$, the replacement of OPC with $25 \%$ FA in one mix, and $40 \%$ GGBFS in another mix, have shown a $15 \%$ and $22 \%$ reduction in carbon footprint, respectively. In comparison to cement production, less than a tenth of the carbon footprint is induced from the GGBFS production, with less than a fifth of the energy required to produce cement [45]. In a recent study by Yu et al. [46], the OPC was replaced by not less than $80 \%$ of FA targeting a low-strength concrete of $30 \mathrm{MPa}$. Two material sustainability indicators were adopted in their study focusing only on the manufacturing process of the material used, which were the embodied energy and the embodied carbon content. Interestingly, the GC mix was observed to exhibit $1 / 4$ to $1 / 3$ of both the embodied energy and the embodied carbon footprint of the conventional M30 concrete mix. This environmental improvement was accompanied with a reduced cost by $35 \%$ of the M30 mix. A case study by Elchalakani et al. [47] was carried out to prepare an efficient and low carbon footprint concrete mix design to build the city of Masdar in the United Arab Emirates. For this purpose, 13 different concrete mixes with $50 \%$ to $80 \%$ replacement of OPC with GGBFS were prepared. The test results of concrete mixes made with GGBFS indicated a $60 \%$ reduction in the carbon footprint, and therefore, a mix with 80\% GGBFS and 20\% OPC was nominated for the future construction of Masdar City.

\subsection{Strength Properties of GC}

In this section, the compressive strength properties of GC, which incorporate industrial SCMs such as GGBFS, FA, SF, or MK as one of its ingredients to replace the OPC, will be studied and analyzed. Most of the collected compression tests in this section were done on 
$100 \mathrm{~mm} \times 200 \mathrm{~mm}$ cylinders and a few of the remaining were $150 \mathrm{~mm} \times 300 \mathrm{~mm}$ cylinders, $100 \mathrm{~mm}$ cubes, and $150 \mathrm{~mm}$ cubes.

\subsubsection{Concrete with Ground Granulated Blast Furnace Slag (GGBFS)}

The slag is a by-product produced during the manufacturing process of steel [48]. It is made up of the same ingredients that make up the OPC, such as alumina, lime, and silica, but with different proportions [49]. As the slag leaves the blast furnace, it must be rapidly chilled to minimize the crystallization of the molten slag and convert it into fine glassy and granulated particles that are smaller than $4.75 \mathrm{~mm}$ in size [50]. The granular product is then ground into fine powder to obtain the GGBFS [51].

The results of compressive, flexural, and split tensile strengths for several studies incorporating the GGBFS at different percentages in concrete are presented in Table S1 in the Supplementary File. It has been recorded that compared to the control mixture with $100 \%$ OPC, lower compressive strength at 7 days was attained when GGBFS was partially incorporated in concrete [50,52-54]. However, the compressive strength of the GGBFS mixture specimens with $25 \%$ replacement was higher at 28 days [52]. For $55 \%$ replacement of GGBFS, similar and higher compressive strength to that of the control specimen was obtained at 56 and 90 days respectively [52], while the higher compressive strength was obtained at both ages in References $[53,55]$ when using $60 \%$ replacement of GGBFS. The optimum level of GGBFS replacement which yields the highest compressive strength was found by Oner and Akyuz [50] to be 55\%. Interestingly, Oner and Akyuz [50] noticed that for the same concrete workability, the water binder $(\mathrm{W} / \mathrm{b})$ ratio reduces as the GGBFS replacement increases, thus the GGBFS has a positive effect on workability as higher compressive strength can be achieved with lower water consumption. For the flexural strength, Khatib and Hibbert [53] showed that at 90 days of curing, the strength of the $60 \%$ GGBFS specimen was enhanced by $19.6 \%$ compared to the control specimen. Keeping in mind that the flexural behavior is sensitive to microcracks, the finer particles of GGBFS along with the secondary pozzolanic reaction can reduce the pore connectivity in hardened concrete and as a result, enhance the flexural strength $[45,56]$. A similar observation was recorded by Guneyisi and Gesoglu [57], where higher compressive and split tensile strengths were achieved at a long time period of 90 days with a replacement level of $60 \%$ of GGBFS.

The lower strength of GGBFS concrete at early ages was mainly attributed to the slow pozzolanic reaction of GGBFS, which depends on the calcium hydroxide $\mathrm{Ca}(\mathrm{OH})_{2}$ availability forms at later ages [50]. Through the pozzolanic reaction, an extra calcium silicate hydrate (C-S-H) gel will be generated, which will densify the microstructure of concrete, thus higher compressive strength of GGBFS concrete is obtained [55]. To enhance the early strength of GGBFS concrete and for further creation of the (C-S-H) gel, several studies suggested the addition of $\mathrm{Ca}(\mathrm{OH})_{2}$ as a hydrated lime [58,59]. Although the early strength of GGBFS concrete was low, this deficiency might be eliminated when adding superplasticizers (SP) at a low $\mathrm{W} / \mathrm{b}$ ratio. The results for a $20 \%$ replacement of GGBFS obtained by Johari et al. [60] revealed higher 7-day compressive strength (79.6 MPa) than the control specimen $(74.8 \mathrm{MPa})$ when $14 \mathrm{Kg} / \mathrm{m}^{3}$ of SP was incorporated at a $0.28 \mathrm{~W} / \mathrm{b}$ ratio. Whereas at 28 and 90 days, comparable and higher strength were obtained at the $60 \%$ replacement level.

In Figure 2, the concrete compressive strength values obtained from several tests in the literature $[48,50,52,53,55,57,60-65]$ at 7,28 , and 90 days for different replacement levels of GGBFS at different $\mathrm{W} / \mathrm{b}$ ratios are plotted in Figure $2 \mathrm{a}, \mathrm{c}, \mathrm{e}$. The ratios between concrete compressive strength at different replacement levels of GGBFS to the reference concrete without GGBFS are also plotted in Figure $2 b, d, f$ to show how close the GGBFS concrete specimens are to the control specimens. The total number of tested specimens is 65 . By referring to Figure 2, the following conclusions can be observed: 
- At 7 days, the GGBFS addition resulted in a lower strength compared to the concrete without GGBFS, as indicated in Figure 2b. However, similar, or closer strength, was achievable when $20 \%$ of GGBFS was added with a $\mathrm{W} / \mathrm{b}$ ratio ranging from 0.3 to 0.4 .

- At 7 days, concrete strength of the range 20 to $35 \mathrm{MPa}$ can be achieved when $\mathrm{W} / \mathrm{b}$ is in the range of 0.42 to 0.5 and when the replacement ratio of GGBFS is ranging from $20 \%$ to $60 \%$ (Figure $2 a$ ).

- At 7 days, concrete strength of the range 40 to $60 \mathrm{MPa}$ and 60 to $80 \mathrm{MPa}$ can be achieved when $\mathrm{W} / \mathrm{b}$ is ranging from 0.3 to 0.4 and 0.28 to 0.3 respectively, and when the replacement ratio of GGBFS is ranging from $20 \%$ to $60 \%$ (Figure 2a).

- The 28- and 90-day tests pointed out more gain in the GGBFS concrete than the control concrete, therefore most of the GGBFS mixtures showed closer lower strength, whereas some were greater than the control specimens. This could reflect the effect of a secondary pozzolanic reaction (Figure $2 \mathrm{~d}, \mathrm{f})$.

- At 28 days, similar or closer strength to the reference concrete was achievable when $20 \%$ to $60 \%$ of GGBFS was added with a $\mathrm{W} / \mathrm{b}$ ratio ranging from 0.3 to 0.42 (Figure $2 \mathrm{~d}$ ).

- At 28 days, concrete strength of the range 20 to $35 \mathrm{MPa}$ can be achieved when $\mathrm{W} / \mathrm{b}=0.5$ with a replacement ratio of GGBFS ranging from $20 \%$ to $80 \%$ (Figure $2 \mathrm{c}$ ).

- At 28 days, concrete strength of the range 40 to $60 \mathrm{MPa}$ can be achieved when $\mathrm{W} / \mathrm{b}$ is of the range 0.3 to 0.4 and when the replacement ratio of GGBFS is ranging from $20 \%$ to $80 \%$ (Figure 2c).

- At 90 days, the compressive strength for all concrete mixtures with different GGBFS\% and $\mathrm{W} / \mathrm{b}$ ratios exceeded $40 \mathrm{MPa}$, except for $80 \%$ of the GGBFS mixture at a $\mathrm{W} / \mathrm{b}$ ratio of 0.5 (Figure 2e).

- The ratio of mean GGBFS concrete compressive strength to the $100 \%$ OPC concrete compressive strength $\left(\mathbf{f}_{\mathbf{c}(\mathbf{G G B F S})}^{\prime} / \mathbf{f}_{\mathbf{c}(\mathbf{1 0 0} \% \text { OPC })}^{\prime}\right)$ was noticed to be closer to 1 as time passed. This reflects the effect of pozzolanic reaction, which develops at later ages by reacting with the hydrated lime to densify the microstructure of concrete, thus, increasing compressive strength.

\subsubsection{Concrete with Fly Ash (FA)}

The FA is a fine powder by-product resulting as a residue from the burning of pulverized coal at high temperatures in electric generation power plants. It is a pozzolan that comprises mainly silica and alumina, which when mixed with water and lime $\mathrm{Ca}(\mathrm{OH})_{2}$ forms a similar compound to Portland cement through the pozzolanic reaction [5], but with a denser and less permeable microstructure [66]. It was reported in the literature that among the worldwide FA production, only $25 \%$ was used in the industry [67].

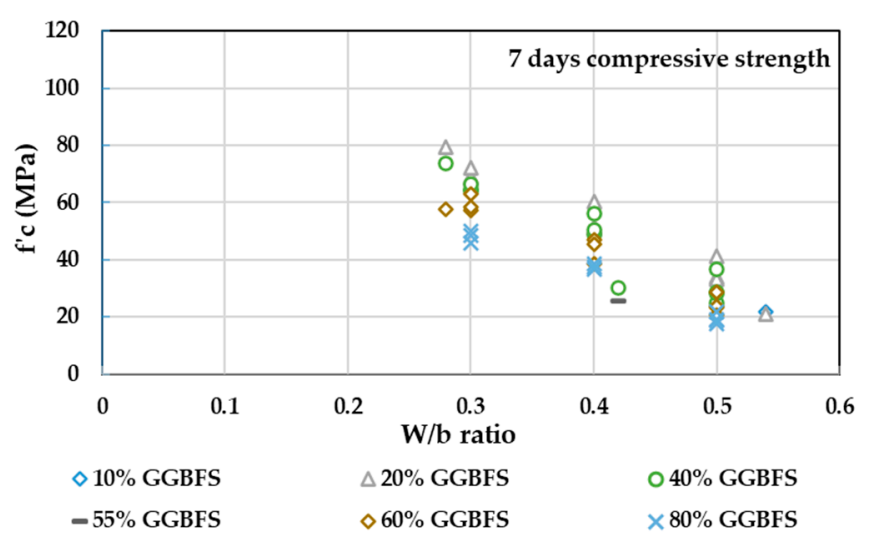

(a)

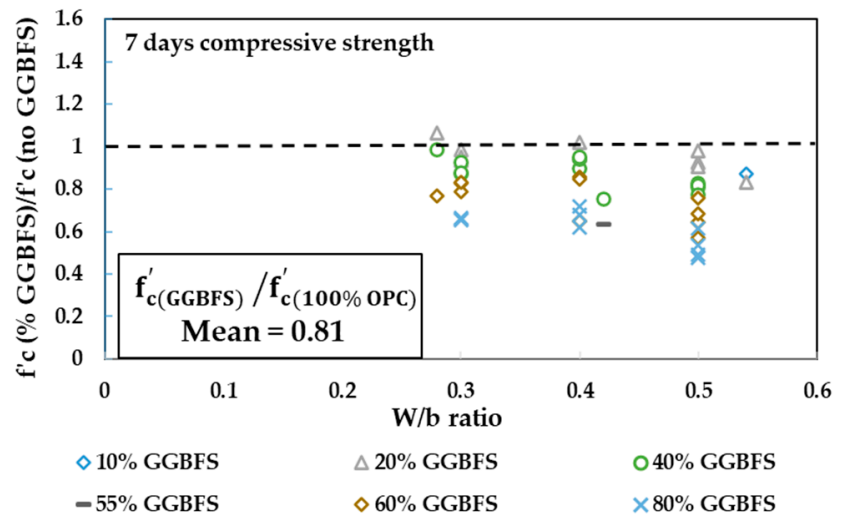

(b)

Figure 2. Cont. 


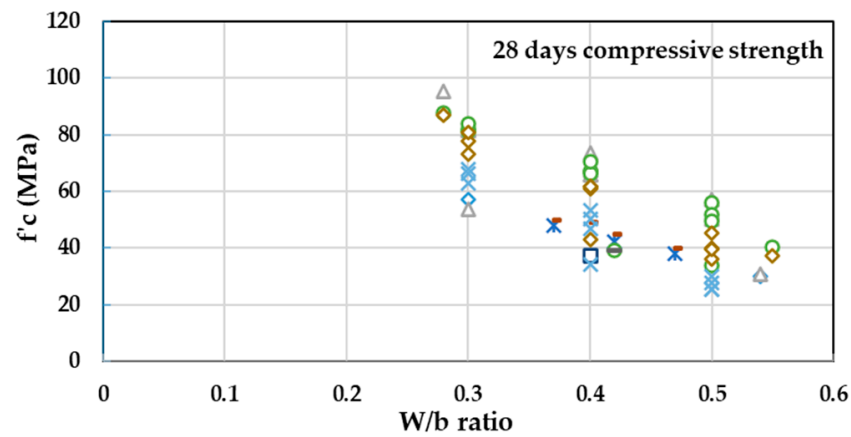

$\diamond 10 \%$ GGBFS $\triangle 20 \%$ GGBFS $* 30 \%$ GGBFS $\quad \circ 40 \%$ GGBFS $\quad-50 \%$ GGBFS $-55 \%$ GGBFS $\diamond 60 \%$ GGBFS $\quad \square 70 \%$ GGBFS $\times 80 \%$ GGBFS

(c)

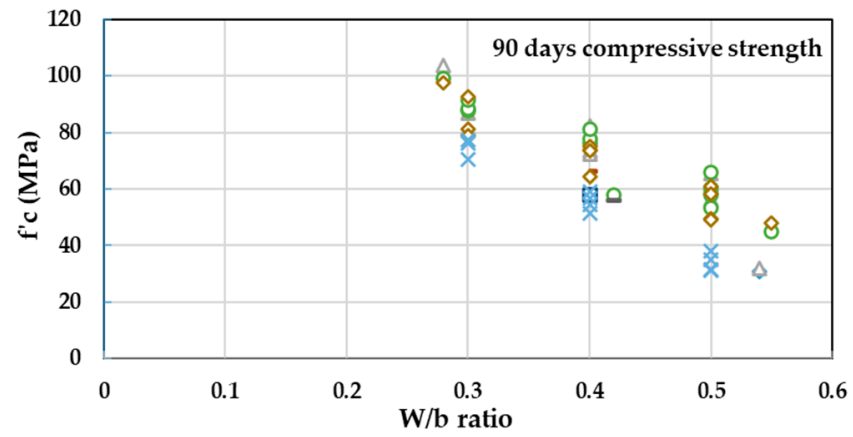

$\diamond 10 \%$ GGBFS $\quad \triangle 20 \%$ GGBFS $\quad 040 \%$ GGBFS $\quad-50 \%$ GGBFS

$-55 \%$ GGBFS $\quad \diamond 60 \%$ GGBFS $\quad \square 70 \%$ GGBFS $\quad \times 80 \%$ GGBFS

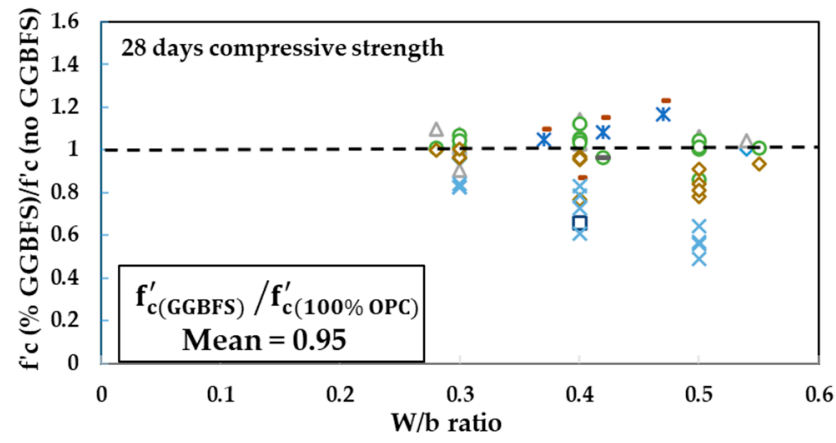

$\diamond 10 \%$ GGBFS $\triangle 20 \%$ GGBFS $\quad * 30 \%$ GGBFS $\quad \circ 40 \%$ GGBFS $\quad-50 \%$ GGBFS

$-55 \%$ GGBFS $\diamond 60 \%$ GGBFS $\quad$ $70 \%$ GGBFS $\times 80 \%$ GGBFS

(d)

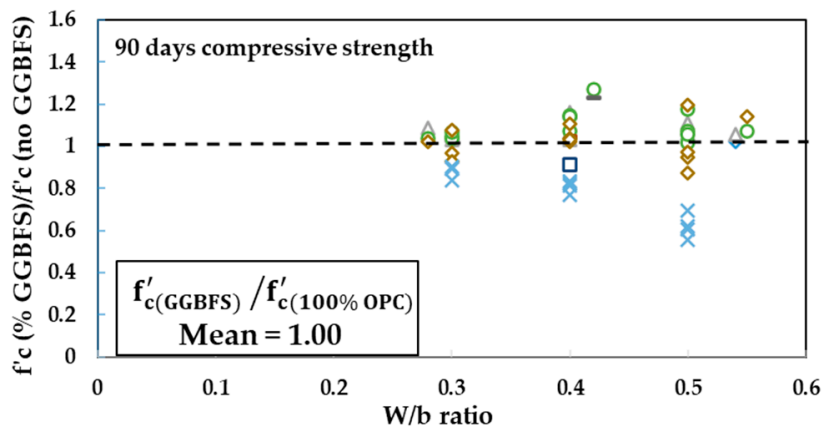

$\begin{array}{llll}\diamond 10 \% \text { GGBFS } & \triangle 20 \% \text { GGBFS } & \circ 40 \% \text { GGBFS } & -50 \% \text { GGBFS } \\ -55 \% \text { GGBFS } & \diamond 60 \% \text { GGBFS } & \square 70 \% \text { GGBFS } & \times 80 \% \text { GGBFS }\end{array}$

(e)

(f)

Figure 2. Concrete with Ground Granulated Blast Furnace Slag (GGBFS) as a partially replacing material for cement. Compressive strength vs. water binder (W/b) ratio at (a) 7 days; (c) 28 days; (e) 90 days. Ratio between compressive strength of concrete with GGBFS to concrete without GGBFS at (b) 7 days; (d) 28 days; (f) 90 days.

Table S2 in the Supplementary File summarizes the findings of compressive, flexural, and split tensile strengths at different ages, where FA was incorporated in concrete at different percentages. According to Naik et al. [68], the addition of a high percentage of FA $(50 \%$ to $70 \%)$ revealed lower compressive strength than the reference specimen without FA. This observation is consistent with Lam et al. [69], however, comparable strength to the reference was achieved at a lower \% of FA (15-25\%) at 28 days, while higher strengths at 56 and 90 days were shown. This was limited to the specimens having low $\mathrm{W} / \mathrm{b}=0.3$, whereas lower strength was recorded at higher $\mathrm{W} / \mathrm{b}$ ratios. Although the results of Bouzoubaa and Lachemi [70] have shown increasing compressive strength with decreasing the FA \% from $50 \%$ to $40 \%$ and $\mathrm{W} / \mathrm{b}$ ratio from 0.45 to 0.35 , the targeted 28 -day strength of $35 \mathrm{MPa}$ was attained for all mixtures. In contrast to previous findings, at $50 \%$ replacement of cement with FA with $\mathrm{W} / \mathrm{b}=0.3$, Atis and Ash [71] found the compressive strength at 7, 28, and 365 days respectively, to be $48.3,66.55$, and $83.60 \mathrm{MPa}$ compared to the control specimen strengths of 52.63, 64.55, and 77.08 MPa. Han et al. [72] concluded that the addition of $30 \%$ of FA has improved the long-term strength at 365 days, while higher early strength at 28 days was obtained when cement was substituted by $10 \%$ of FA. Siddique [73] stated that the compressive strength continued to decrease as the replacement ratio increased from $40 \%$ to $50 \%$ with $\mathrm{W} / \mathrm{b}=0.4$, however, the obtained strengths were sufficient for the use in reinforced concrete structures. It has been demonstrated by Dinakar et al. [74] that for low-strength self-compacting concrete (20 to $30 \mathrm{MPa}$ ), the replacement ratio of FA can reach up to $70 \%$ to $85 \%$, while for higher strength grades (60 to $90 \mathrm{MPa}$ ), the replacement ratio can be in the range of $30 \%$ to $50 \%$. In their analysis, Nath and Sarker [66] concluded that 
when partially replacing cement with fly ash, the 28-day strength will experience a drop if no adjustment to the $\mathrm{W} / \mathrm{b}$ ratio is applied. Therefore, high-strength concrete of $67 \mathrm{MPa}$ can be obtained at 28 days when adjusting the $\mathrm{W} / \mathrm{b}$ ratio from 0.41 in the specimen without FA to 0.31 in the specimen with $40 \%$ of FA. At 56 days, the strength was remarkably increased to reach $88 \mathrm{MPa}$, but no further increase in strength was noticed beyond this age. The results obtained by Durán-Herrera et al. [75] draw the attention toward the inefficient use of FA at a replacement ratio exceeding $30 \%$ when $\mathrm{W} / \mathrm{b}$ is equal to or above 0.5 , where a significant drop in the strength of $45 \%$ was reported at 28 days. Beyond 7 days, the authors of References [76,77] pointed out that the gain in strength for the FA concrete was greater than the reference concrete at $28,56,90$, and 365 days. By adjusting the $\mathrm{W} / \mathrm{b}$ ratio, the reference 28-day strength was exceeded at a replacement level of $20 \%$ to $40 \%$ of FA, but for a higher replacement level of $60 \%$ to $80 \%$ of FA, the reference strength was exceeded at 90 days [78]. In addition, the FA concrete indicated a superior flexural strength from 28 to 365 days.

The increase in strength when cement was partially replaced with FA is attributed to the re-crystallized calcium carbonate and the creation of additional (C-S-H) gel in the cementitious matrix, which was formed by the interaction between FA and $\mathrm{Ca}(\mathrm{OH})_{2}$ that reduces the porosity of both the transition zone and the matrix [79]. Also, the finer particles that fill the voids between aggregates along with their spherical shape will produce a better particle packing and a denser paste, thus the strength will increase [80].

In Figure 3, the concrete compressive strength values obtained from the literature [68-77,79-82] at 7, 28, and 90 days for different replacement levels of FA at different $W / b$ ratios are plotted in Figure $3 a, c, e$. The ratios between concrete compressive strength at different replacement levels of FA to the reference concrete without FA are also plotted in Figure $3 b, d, f$ to show how close the FA concrete specimens are to the control specimens. The total number of tested specimens is 63 . By referring to Figure 3, the following conclusions can be observed:

- At 7 days, the FA addition resulted in a lower strength compared to the concrete without FA, however similar or closer strength was achievable when $10 \%$ to $15 \%$ of FA was added with a $\mathrm{W} / \mathrm{b}$ ratio ranging from 0.3 to 0.4 (Figure $3 \mathrm{~b}$ ).

- At 7 days, concrete strength of the range 20 to $35 \mathrm{MPa}$ can be achieved when $\mathrm{W} / \mathrm{b}$ is in the range of 0.4 to 0.55 and when the replacement ratio of FA is ranging from $10 \%$ to $30 \%$ (Figure $3 a$ ).

- At 7 days, concrete strength of the range 40 to $60 \mathrm{MPa}$ can be achieved when $\mathrm{W} / \mathrm{b}$ is ranging from 0.24 to 0.35 and when the replacement ratio of FA is ranging from $10 \%$ to $45 \%$ (Figure $3 a$ ).

- Similar to GGBFS concrete, the 28-day tests of FA concrete were observed to show more gain in strength than the control concrete, therefore most of the FA mixtures showed closer lower strength and few were greater than the control specimens, except for those mixtures having greater than $40 \% \mathrm{FA}$ and $\mathrm{W} / \mathrm{b}$ ratio from 0.4 to 0.6 , where no evident enhancement in strength was recorded (Figure 3d).

- At 28 days, similar or closer strength to the reference concrete was achievable when $10 \%$ to $25 \%$ of FA was added with a $\mathrm{W} / \mathrm{b}$ ratio ranging from 0.24 to 0.35 (Figure $3 \mathrm{~d}$ ).

- At 28 days, concrete strength of the range 20 to $35 \mathrm{MPa}$ can be achieved with W/b of the range 0.5 to 0.6 or 0.24 to 0.45 , with a replacement ratio of FA ranging from $10 \%$ to $30 \%$ or $40 \%$ to $60 \%$, respectively (Figure $3 \mathrm{c}$ ).

- At 28 days, a higher strength grade of the range 40 to $60 \mathrm{MPa}$ and 60 to $80 \mathrm{MPa}$ can be achieved when $\mathrm{W} / \mathrm{b}$ is of the range 0.27 to 0.4 and 0.24 to 0.36 and when the replacement ratio of FA is ranging from $10 \%$ to $55 \%$ and $10 \%$ to $40 \%$, respectively (Figure 3c).

- At 90 days, the FA mixtures exhibited more gain in strength than the $0 \%$ FA mixtures. This could reflect the effect of secondary pozzolanic reaction, which produces a higher rate of strength gaining in the long term (Figure 3f). 
- The ratio of mean $\left(\mathbf{f}_{\mathbf{c} \text { (FA) }}^{\prime} / \mathbf{f}_{\mathbf{c}(100 \% \text { OPC })}^{\prime}\right)$ was recorded as 0.66 at 7 days and it keeps increasing up to 0.93 at 90 days. Although this reflects the effect of pozzolanic reaction as in the case of GGBFS, the strength is developing at a slower rate.

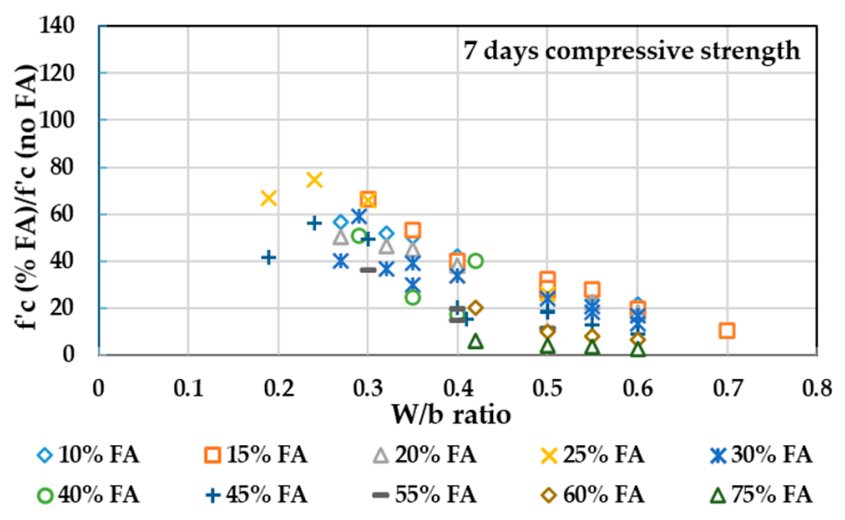

(a)

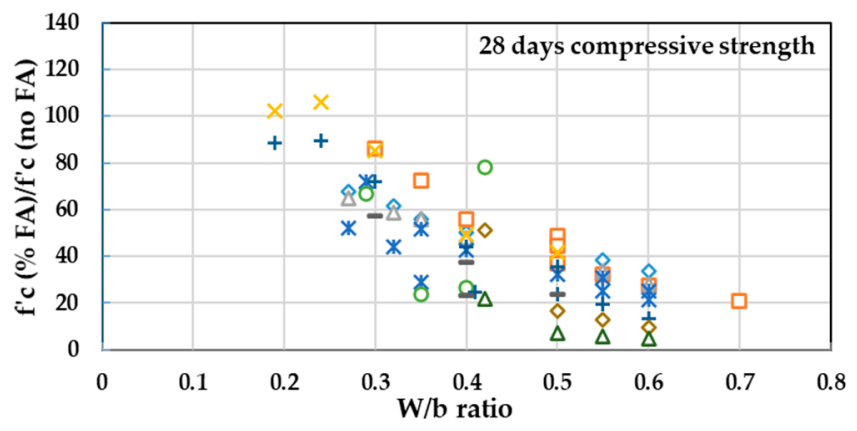

$\diamond \mathbf{1 0} \% \mathrm{FA} \quad \square \mathbf{1 5} \% \mathrm{FA} \quad \triangle \mathbf{2 0} \% \mathrm{FA} \quad \times \mathbf{2 5} \% \mathrm{FA} \quad \approx \mathbf{3 0} \% \mathrm{FA}$ $\circ 40 \% \mathrm{FA} \quad+45 \% \mathrm{FA} \quad-55 \% \mathrm{FA} \quad \diamond 60 \% \mathrm{FA} \quad \triangle 75 \% \mathrm{FA}$

(c)

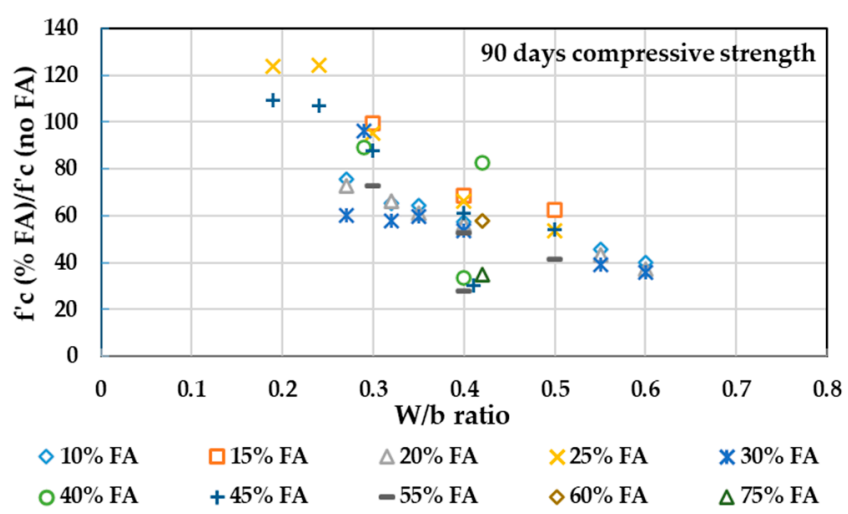

(e)

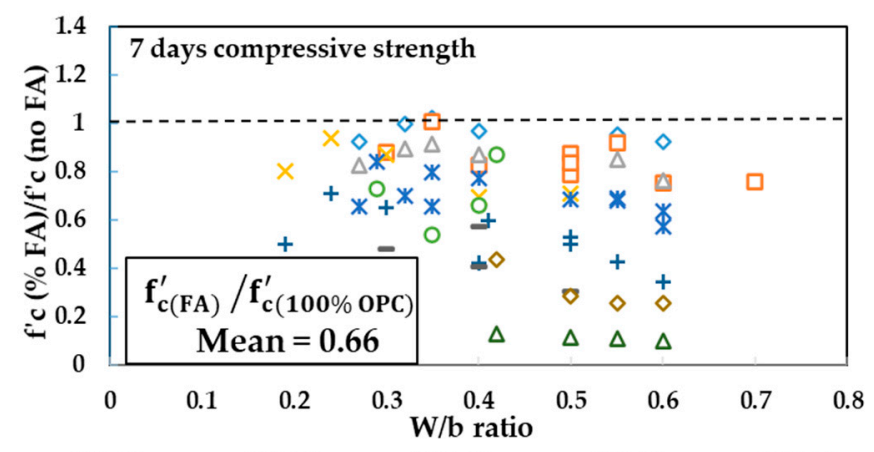

$\diamond 10 \% \mathrm{FA} \quad \square \mathbf{1 5} \% \mathrm{FA} \quad \triangle 20 \% \mathrm{FA} \quad \times 25 \% \mathrm{FA} \quad \approx 30 \% \mathrm{FA}$ $\circ 40 \% \mathrm{FA} \quad+45 \% \mathrm{FA} \quad-55 \% \mathrm{FA} \quad \diamond 60 \% \mathrm{FA} \quad \triangle 75 \% \mathrm{FA}$

(b)

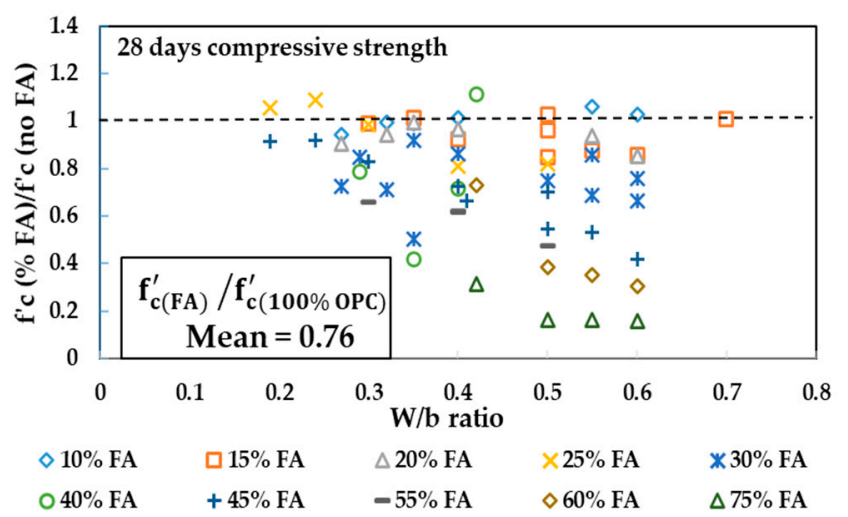

(d)

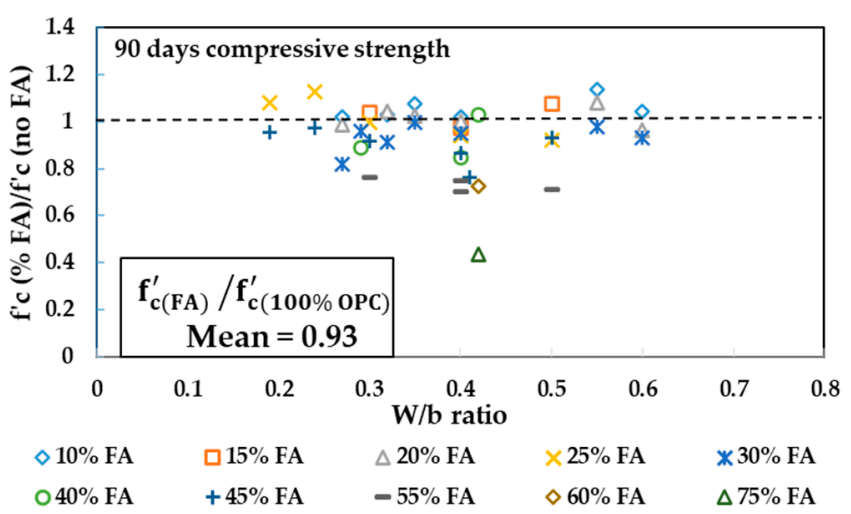

(f)

Figure 3. Concrete with Fly ash (FA) as a partially replacing material for cement. Compressive strength vs. W/b ratio at (a) 7 days; (c) 28 days; (e) 90 days. Ratio between compressive strength of concrete with FA to concrete without FA at (b) 7 days; (d) 28 days; (f) 90 days. 


\subsubsection{Concrete with Silica Fume (SF)}

The SF is another efficient pozzolan with a highly fragmented structure, that when used in the concrete, reacts with the lime produced from the hydrated cement to reduce the pore size volume and capillaries in the cement paste [83]. SF is a waste product produced in the metallurgical industry from silicon alloys such as ferrosilicon, metallic silicon, etc. [84]. Its tiny particles are characterized by microscopic spherical shape with a diameter ranging from 0.1 to 0.5 micrometers $(\mu \mathrm{m})$ [85].

In the Supplementary File, Table S3 lists the compressive, flexural, and split tensile strength results at different ages for several studies incorporating the SF at different percentages in concrete. The most prominent outcome to emerge from Table S3 is the higher early compressive strength of SF concrete than the reference concrete at 7 days [83,86-91]. The compressive strength continues to increase significantly up to 56 days, however, only a marginal increase was recorded beyond this age [86-88]. The flexural strength was also enhanced upon the SF addition, and the optimum amount of SF was found to be $15 \%$. This is in complete agreement with reference [90]. Although exceeding this limit decreases the strength, high-strength concrete of $77.5 \mathrm{MPa}$ was still achievable at $25 \%$ of SF with a W/b ratio of 0.3 and SP of $12.6 \mathrm{~kg} / \mathrm{m}^{3}$ [86]. Wong and Razak [88] prepared several concrete mixes having $0 \%$ to $15 \%$ by weight of cement as $\mathrm{SF}$ with different $\mathrm{W} / \mathrm{b}$ ratios of $0.27,0.3$, and 0.33 . Their results observed no immediate enhancement in strength at 3 days due to the SF addition, but from 7 days onward, higher strength than the control concrete was obtained at all ages until reaching $17 \%$ increment at 90 days for $10 \% \mathrm{SF}$ concrete. This could be referred to the slow nature of pozzolanic activity at early ages and the dilution effect of pozzolan. It was also noticed that reducing $\mathrm{W} / \mathrm{b}$ ratio from 0.3 to 0.27 did not excite a significant increase in strength as expected. In their research, Bhanja and Sengupta [92] have also studied the effect of several $\mathrm{W} / \mathrm{b}$ ratios, namely $0.27,0.3,0.38$, and 0.42 on concrete compressive, flexural, and tensile strengths with the SF incorporation at $0 \%$ to $30 \%$ by weight of cement. It emerged from their results that the optimum replacement level of SF for tensile strength was a function of the $\mathrm{W} / \mathrm{b}$ ratio in the mix, which confirms the previous finding [70]. The optimum replacement level for tensile strength at 28 days was found to be in the range of $5 \%$ to $10 \%$, while for compressive and flexural strengths, it was found to be in the range of $15 \%$ to $25 \%$. In comparison to split tensile strength, the flexural strength demonstrated greater improvement due to SF incorporation.

From the previous findings of GGBFS and FA, the 7- and 28-day strengths were reduced compared to the control specimens without GGBFS or FA, whereas comparable or higher strengths were achieved at later ages of 56 and 90 days. In contrast, the early age strengths at and after 7 days have shown a clear enhancement over the control concrete when cement was partially replaced with SF. This was attributed to the smaller size particle of SF than the GGBFS and FA, which leads to an increase in the pozzolanic reaction between $\mathrm{SiO}_{2}$ from $\mathrm{SF}$ and $\mathrm{Ca}(\mathrm{OH})_{2}$ resulting from the hydration of cement [93-96], which generates a C-S-H gel that grows into the capillary voids of the mortar, thus forming a denser microstructure. Furthermore, the physical role of SF as a filler also aids in the strength development, as the fine particles of SF would lead to a reduction in porosity of the transition zone, and hence the interlocking mechanism between the paste and aggregate is boosted [89,97].

In Figure 4, the concrete compressive strength values obtained from the literature $[83,86-92,98,99]$ at 7,28 , and 90 days for different replacement levels of SF at different $\mathrm{W} / \mathrm{b}$ ratios are plotted in Figure $4 \mathrm{a}, \mathrm{c}, \mathrm{e}$. The ratios between concrete compressive strength at different replacement levels of $\mathrm{SF}$ to the reference concrete without $\mathrm{SF}$ are also plotted in Figure $4 b, d, f$ to show how close the FA concrete specimens are to the control specimens. The total number of tested specimens is 78 . By referring to Figure 4, the following conclusions can be observed:

- Unlike GGBFS and FA, the SF addition resulted in approximately a similar and, in most cases, a higher compressive strength compared to the concrete without $\mathrm{SF}$ at 7 days (Figure $4 b$ ). 
- At 7 days, concrete strength of the range 20 to $35 \mathrm{MPa}$ can be achieved when $\mathrm{W} / \mathrm{b}$ is in the range of 0.36 to 0.57 and when the replacement ratio of $\mathrm{SF}$ is ranging from $5 \%$ to $20 \%$ (Figure $4 a)$.

- At 7 days, concrete strength of the range 40 to $60 \mathrm{MPa}$ can be achieved when $\mathrm{W} / \mathrm{b}$ is ranging from 0.3 to 0.5 and when the replacement ratio of $\mathrm{SF}$ is ranging from $5 \%$ to $15 \%$ (Figure $4 a$ ).

- The 28-day tests resulted in a higher gain in strength in the SF concrete than the control concrete. Therefore, all the SF mixtures showed greater strength than the control specimens (Figure $4 \mathrm{~d}$ ).

- At 28 days, most of the compressive strength values were $>40 \mathrm{MPa}$. High-strength grades of the range 40 to $60 \mathrm{MPa}$ and 60 to $90 \mathrm{MPa}$ can be achieved when $\mathrm{W} / \mathrm{b}$ is of the range 0.35 to 0.5 and 0.26 to 0.4 and when the replacement ratio of SF is ranging from $5 \%$ to $20 \%$ and $5 \%$ to $25 \%$, respectively (Figure $4 \mathrm{c}$ ).

- At 90 days, the SF mixtures continue to increase in strength beyond $100 \mathrm{MPa}$ for $10 \%$ to $20 \%$ of $S F$ concrete with a $\mathrm{W} / \mathrm{b}$ ratio of 0.27 to 0.3 (Figure $4 \mathrm{e}$ ).

- The ratio of mean $\left(\mathbf{f}_{\mathbf{c}(\mathbf{S F})}^{\prime} / \mathbf{f}_{\mathbf{c}(100 \% \text { OPC })}^{\prime}\right)$ was reported as 1.14 at 7 days, then it was increased up to 1.24 at 28 days, but at 90 days, the mean ratio remained as 1.24. This indicates the fast and minor strength development at early and later ages, respectively.

\subsubsection{Concrete with Metakaolin (MK)}

Unlike GGBFS, FA, and SF, the MK is not a by-product, but it is made by the calcination of high-purity kaolin clay at a temperature ranging from 650 to $800{ }^{\circ} \mathrm{C}$ [100]. The exposure of the kaolin clay to this range of temperature is done to break down the crystalline structure and remove the chemically bound water from the interstices of the kaolin so that the material is converted into an amorphous aluminosilicate called MK [91]. During its manufacturing, the MK passes through a well-controlled process that carefully refines the particles to drive off the inert impurities, lighten its color, and results in a high reactivity powder with high consistency in performance and structure [91]. In comparison to a cement particle size of $10 \mu \mathrm{m}$, the MK has a median particle size of $1.3 \mu \mathrm{m}$ [101,102].

Different studies that partially substituted the OPC with MK are provided in Table S4 of the Supplementary File. Zhang and Malhotra [101] reported that the compressive strength of $10 \%$ MK concrete has exhibited higher compressive strength values than the control concrete at all ages up to 180 days. This observation was further supported by References [103-106] and when compared to SF, the MK showed a faster increment in strength at the early ages of 3 days, which also concurs well with references [98,102]. At a higher replacement level of $20 \% \mathrm{MK}$, Khatib and Hibbert [53] outlined that no further enhancement in strength was recorded. Also, Khatib and Hibbert [53] concluded that the replacement level of $10 \% \mathrm{MK}$ was the best, and it was found to be superior to SF in terms of strength development, particularly at an early age of 3 days, where higher strength than the control was triggered, while for SF, higher strength than control was triggered at or after 7 days. Dinakar et al. [107] indicated that at an optimum replacement level of $10 \%$ $\mathrm{MK}$, a strength value of $100 \mathrm{MPa}$ can be obtained at a low $\mathrm{W} / \mathrm{b}$ ratio of 0.3 . The same concrete mix has resulted in 28 days splitting tensile strength of $5.15 \%$ of its compressive strength with a relatively high elastic modulus. Ramezanianpour and Jovein [108] stated that the gaining level of compressive strength was developed at lower $\mathrm{W} / \mathrm{b}$ and with the increasing curing period of concrete. In their study, the optimum amount of MK for concrete with a $\mathrm{W} / \mathrm{b}$ ratio of 0.35 and 0.4 were $10 \%$ and $12.5 \%$, respectively. However, according to the literature, the optimum amount of MK for 40 to $50 \mathrm{MPa}$ concrete at a $0.5 \mathrm{~W} / \mathrm{b}$ ratio was found to be $20 \%[53,102,109-111]$, whereas it was found to be $10 \%$ for 80 to $100 \mathrm{MPa}$ concrete at $\mathrm{W} / \mathrm{b}$ of $0.3[28,88,98,101,105]$. The fast strength development of MK in concrete was mainly attributed to the pore filling effect and the fast pozzolanic reaction of $\mathrm{MK}$ with the liberated $\mathrm{Ca}(\mathrm{OH})_{2}$ during cement hydration, which creates more bonds among the densely packed particles through the formation of C-S-H gel [112]. Moreover, 
this could also be attributed to a higher content of aluminum oxide $\left(\mathrm{Al}_{2} \mathrm{O}_{3}\right)$, which caused much higher pozzolanic activity [113].

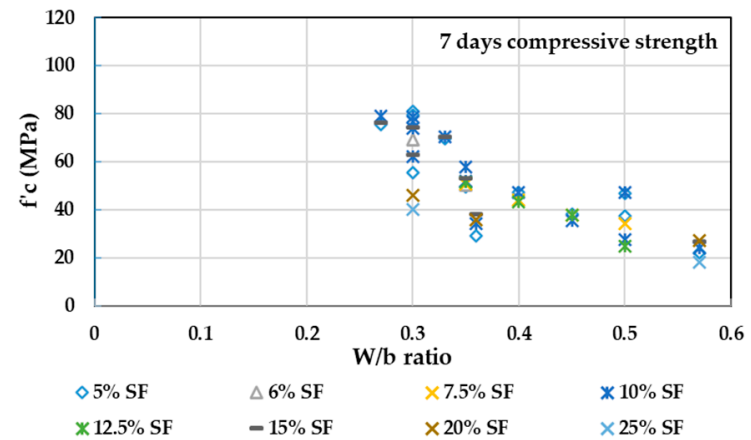

(a)

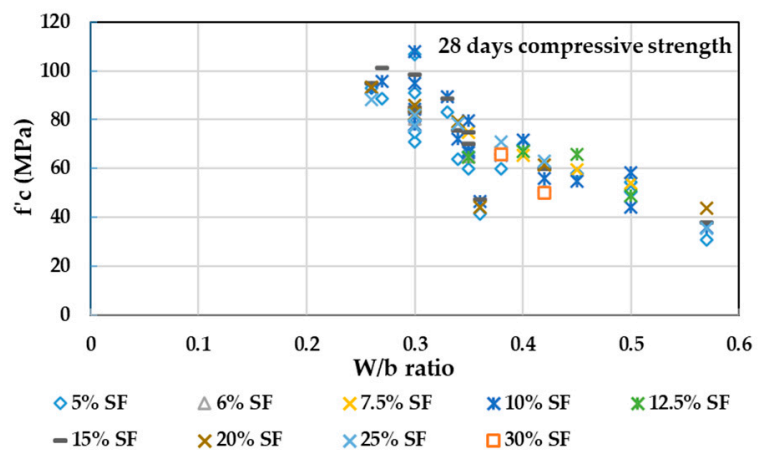

(c)

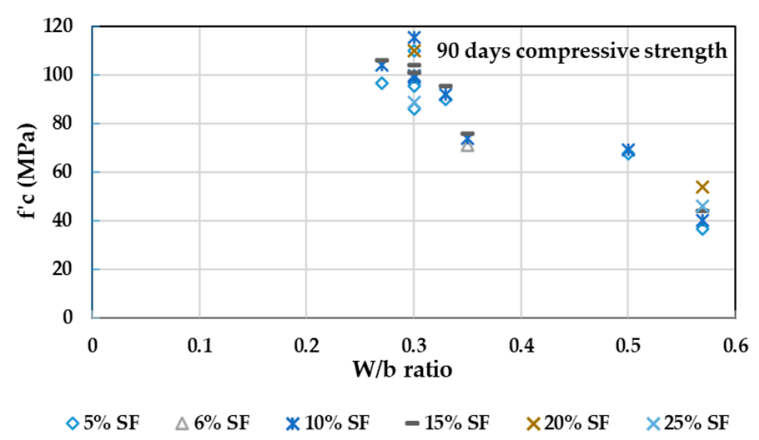

(e)

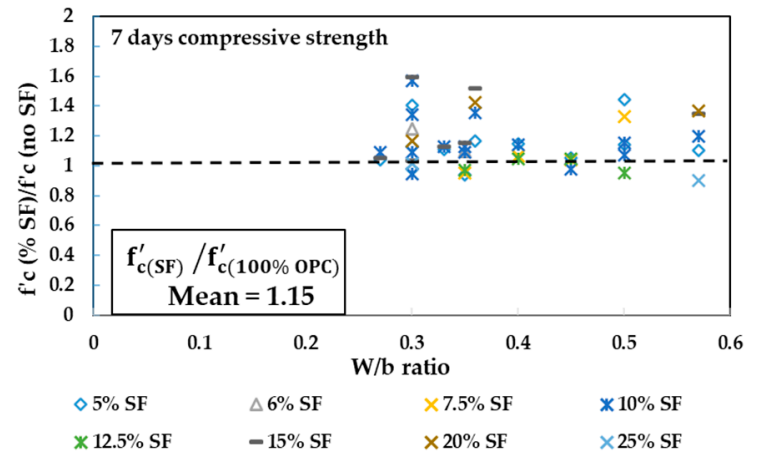

(b)

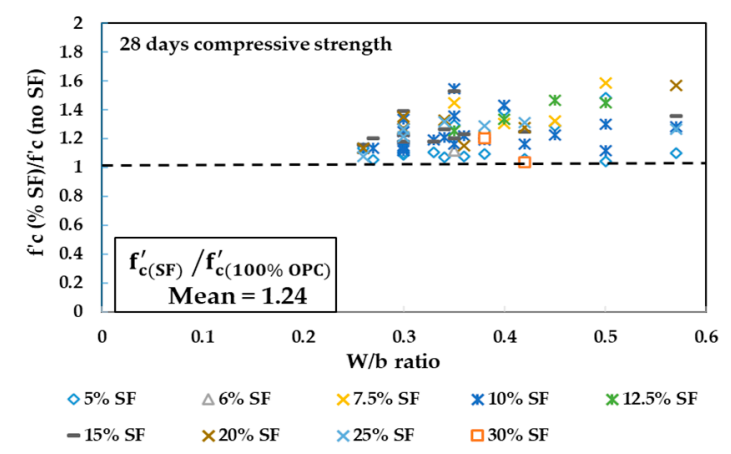

(d)

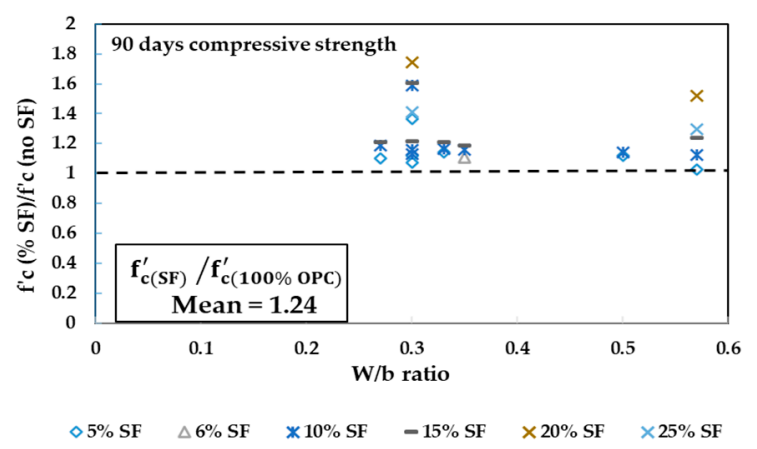

(f)

Figure 4. Concrete with Silica fume (SF) as a partially replacing material for cement. Compressive strength vs. W/b ratio at (a) 7 days; (c) 28 days; (e) 90 days. Ratio between compressive strength of concrete with SF to concrete without SF at (b) 7 days; (d) 28 days; (f) 90 days.

In Figure 5, the concrete compressive strength values obtained from the literature $[53,74,88,91,98,101-103,106,108]$ at 7, 28, and 90 days for different replacement levels of $\mathrm{MK}$ at different $\mathrm{W} / \mathrm{b}$ ratios are plotted in Figure 5a,c,e. The ratios between concrete compressive strength at different replacement levels of $\mathrm{MK}$ to the reference concrete without MK are also plotted in Figure $5 b, d, f$ to show how close the MK concrete specimens are to the control specimens. The total number of tested specimens is 51. By referring to Figure 5, the following conclusions can be observed: 
- Similar to SF, the MK addition revealed higher early compressive strength than the concrete without MK at 7 days. However, lower strength was obtained when replacing cement by $30 \%$ of MK at $W / b$ of 0.32 to 0.36 (Figure $5 b$ ).

- At 7 days, most of the compressive strength values were $>40 \mathrm{MPa}$. This clearly illustrates the high efficiency of MK in attaining high-strength values at early ages (Figure 5b).

- At 7 days, concrete strength of the range 40 to $60 \mathrm{MPa}$ can be achieved when $\mathrm{W} / \mathrm{b}$ is ranging from 0.32 to 0.5 and when the replacement ratio of $\mathrm{MK}$ is ranging from $10 \%$ to $30 \%$ (Figure $5 \mathrm{a}$ ).

- The 28-day tests have shown more strength gain in the MK concrete than at 7 days. High strength grades of the range 60 to $80 \mathrm{MPa}$ can be achieved when $\mathrm{W} / \mathrm{b}$ is of the range 0.3 to 0.36 and when the replacement ratio of $\mathrm{MK}$ is ranging from $10 \%$ to $20 \%$ (Figure 5c).

- At 28 days, high strength grades of the range 80 to $100 \mathrm{MPa}$ can be achieved when $\mathrm{W} / \mathrm{b}$ is of the range 0.27 to 0.33 and when the replacement ratio of $\mathrm{MK}$ is $5 \%$ to $15 \%$, respectively (Figure $5 c$ ).

- At 90 days, the MK mixtures continue to increase in strength beyond $100 \mathrm{MPa}$ for $5 \%$ to $20 \%$ of $\mathrm{MK}$ with a $\mathrm{W} / \mathrm{b}$ ratio of 0.27 to 0.3 (Figure $5 \mathrm{e}$ ).

- Even at 28 (Figure $5 \mathrm{~d}$ ) and 90 days (Figure $5 \mathrm{f}$ ), when replacing cement by $30 \%$ of MK at $\mathrm{W} / \mathrm{b}$ of 0.32 to 0.36 , lower strength than the reference was shown, whereas higher strength was achieved at a higher $\mathrm{W} / \mathrm{b}$ ratio of 0.44 .

- $\quad$ Based on the ratios of mean $\left(\mathbf{f}_{\mathbf{c}(\mathbf{M K})}^{\prime} / \mathbf{f}_{\mathbf{c}(100 \% \text { OPC })}^{\prime}\right)$ which were reported as 1.15, 1.16, and 1.08 at 7, 28, and 90 days respectively, the MK is very effective in gaining higher early strength at 7 days than the $100 \%$ OPC concrete, but this effect turned out to be marginal at later ages of 90 days.

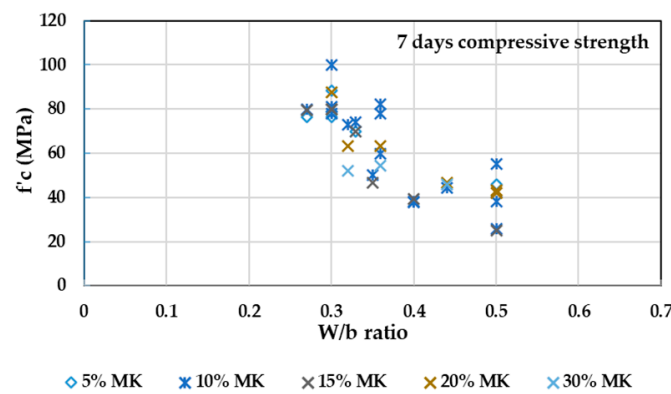

(a)

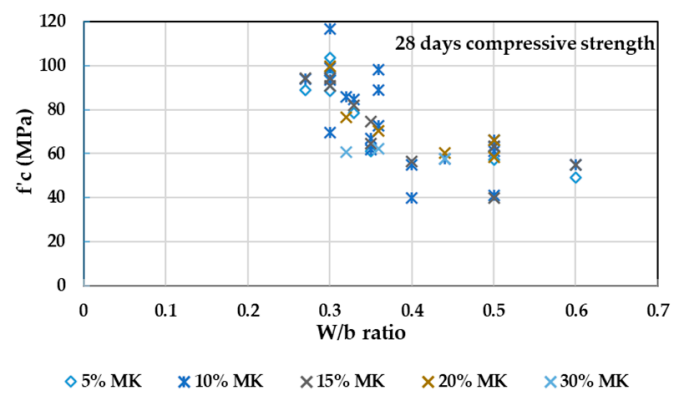

(c)

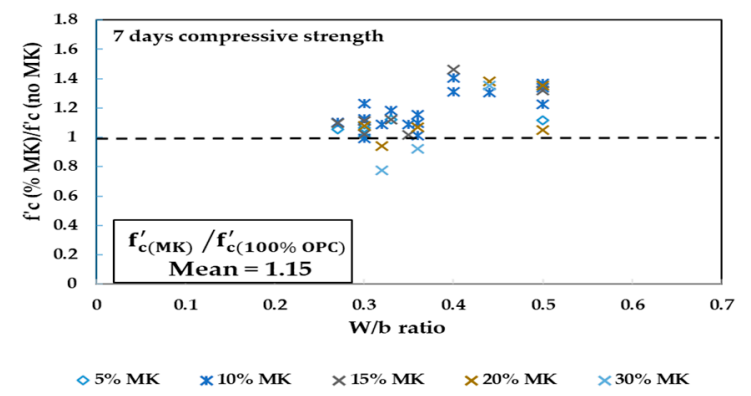

(b)

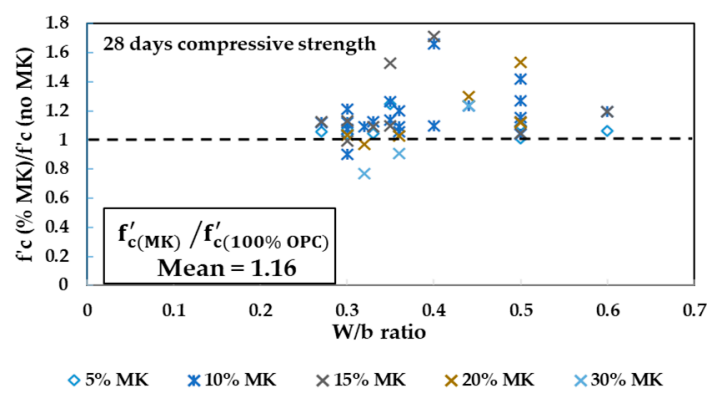

(d)

Figure 5. Cont. 


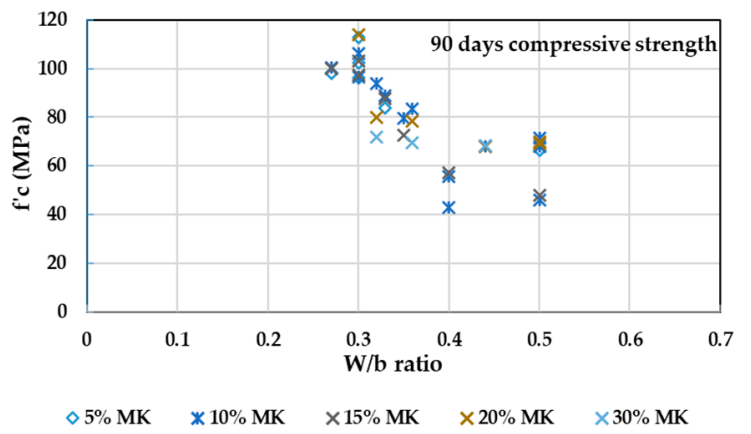

(e)

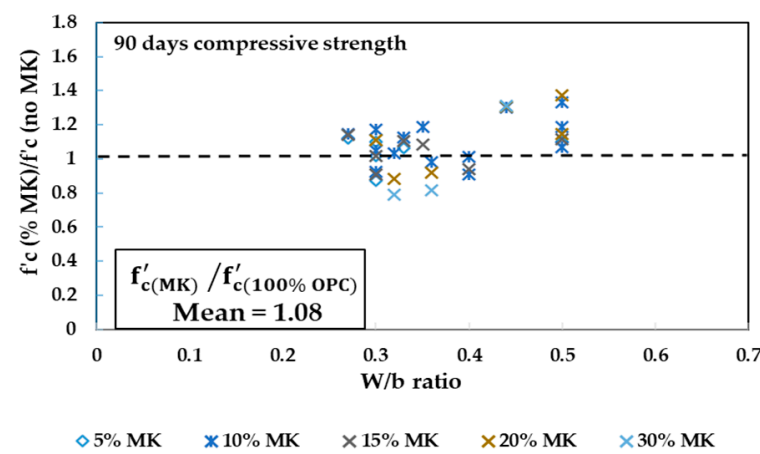

(f)

Figure 5. Concrete with Metakaolin (MK) as a partially replacing material for cement. Compressive strength vs. W/b ratio at (a) 7 days; (c) 28 days; (e) 90 days. Ratio between compressive strength of concrete with MK to concrete without MK at (b) 7 days; (d) 28 days; (f) 90 days.

\subsection{Durability Performance of GC}

Durability is one of the most frequently stated concerns with concrete as the deterioration of RC elements could be related, at most, to the harsh environmental exposures [65]. Hence, several durability studies will be presented in this section to discuss the durability performance of GC.

\subsubsection{Elevated Temperature}

Poon et al. [114] evaluated the effect of elevated temperature up to $800{ }^{\circ} \mathrm{C}$ on the performance of eight normal and high-strength concrete mixes, where MK replaced OPC at $0 \%, 5 \%, 10 \%$, and $20 \%$. To achieve high-temperature exposure, the test specimens were placed in an automatic electric furnace. Compared to concretes with OPC, FA, and $\mathrm{SF}$, the MK concrete mixes attained higher compressive strength up to $400{ }^{\circ} \mathrm{C}$, whereas beyond $400{ }^{\circ} \mathrm{C}$, a sharp reduction in compressive strength was attained, followed by severe cracking and explosive spalling, which is attributed to its dense micro-structure that allows the build-up of pore pressure by steam [115]. However, the concrete mix with 5\% of MK showed better performance than the corresponding concretes at all temperatures without spalling at failure [114].

The mechanical behavior of concrete, where the OPC was replaced by weight with $20 \%, 40 \%$, and $60 \%$ of GGBFS and exposed to temperatures up to $350{ }^{\circ} \mathrm{C}$ has been explored in Reference [116]. It was pointed out in the authors' analysis that the deterioration in compressive strength, splitting tensile strength, and elastic modulus of GGBFS concrete at all elevated temperatures $\left(100,200\right.$, and $350{ }^{\circ} \mathrm{C}$ ) remained below $40 \%$ at 28 and 56 days compared to the mix at room temperature of $27^{\circ} \mathrm{C}$. Among all GGBFS mixes, the $20 \%$ GGBFS mix provided the best performance and it could be suitably implemented in nuclear structures.

Li et al. [117] also utilizes GGBFS in concrete with replacement ratios of $10 \%, 30 \%$, and $50 \%$ by weight of OPC to evaluate their performance under high-temperature exposures from 150 to $700{ }^{\circ} \mathrm{C}$ for 90 days. The mixes with a higher content of GGBFS have shown higher carbonation depth, and in comparison to the control mix with $100 \%$ OPC, the depth was measured as twice as great in the GGBFS concrete when the temperature was raised above $300{ }^{\circ} \mathrm{C}$. The compressive strength was decreased with increased temperature, and this was more pronounced at temperatures higher than $400{ }^{\circ} \mathrm{C}$. As an example, the reductions in compressive strengths for concrete with $0 \%, 10 \%, 30 \%$, and 50\% of GGBFS were measured at $500{ }^{\circ} \mathrm{C}$ as $40 \%, 38 \%, 56 \%$, and $59 \%$ respectively, compared to the unheated specimens. Moreover, the deterioration in the elastic modulus of GGBFS concretes was 
more severe than the unheated specimens with percent retentions of $22 \%, 25 \%$, and $27 \%$ respectively, for concretes with $10 \%, 30 \%$, and $50 \%$ of GGBFS.

The mechanical and durability performances of high-performance concrete mixes with $5 \%$ to $20 \%$ of MK and $20 \%$ to $60 \%$ FA were also studied under elevated temperatures in Reference [118]. The concrete mixes were exposed to temperature values ranging from 27 to $800{ }^{\circ} \mathrm{C}$ followed by slow cooling in air or fast cooling in water. Generally, it was observed that the exposure to $400{ }^{\circ} \mathrm{C}$ followed by fast cooling caused more severe degradation in compressive strength. From a durability perspective, the values of sorptivity and chloride permeability were significantly increased for all mixes between 400 to $600{ }^{\circ} \mathrm{C}$ due to the increased pore area fraction at a higher temperature. However, at normal temperature, the MK specimens demonstrated higher resistance against water penetration than the FA and CC specimens. On the other hand, the lowest sorptivity was attained for the $20 \%$ FA mix at $600{ }^{\circ} \mathrm{C}$ and above.

Recently, Rashad and Sadek [113] attempted to improve the compressive strength of $70 \%$ GGBFS paste exposed to elevated temperatures, namely $400,600,800$, and $1000{ }^{\circ} \mathrm{C}$ for $2 \mathrm{~h}$. The authors suggested the addition of $2 \%$ to $10 \%$ of MK as a replacement ratio for the GGBFS by weight. Their results have shown that the compressive strength was enhanced with the increased content of MK before and after the exposure to elevated temperatures. At 800 to $1000{ }^{\circ} \mathrm{C}$, the residual compressive strength for pastes with $2 \%, 4 \%, 6 \%, 8 \%$, and $10 \%$ of MK were $10 \%, 15 \%, 20 \%, 27 \%$, and $35 \%$ higher respectively, than the control mix with $0 \% \mathrm{MK}$.

\subsubsection{Sulfate Attack, Chloride Ion Penetration, and Freezing and Thawing}

Li and Zhao [119] assessed the short- and long-term resistance to sulfate attack of three concrete mixes, namely CC, concrete with $40 \%$ FA, and concrete with a combination of 25\% FA and $15 \%$ GGBFS (GGFAC). The test was carried following the Chinese Standard GBJ82-85 by immersing specimens with a size of $100 \mathrm{~mm} \times 100 \mathrm{~mm} \times 300 \mathrm{~mm}$ in a solution with $2 \%$ of $\mathrm{H}_{2} \mathrm{SO}_{4}$ at room temperature. After 50 weeks of exposure, the GGFAC was superior to CC and 40\% FA concrete in terms of sulfate attack resistance. Moreover, the change in weight of GGFAC was slow and remained below $8 \%$. This was followed by $10 \%$ in the $40 \%$ FA mix, while in CC, the weight change reached as much as $16 \%$.

McCarthy and Dhir [120] carried out durability-related tests including chloride diffusion, permeability, and absorption for concrete with $45 \%$ FA as a cement component. The chloride diffusion test was done on a concrete cylinder slice of $100 \mathrm{~mm}$ diameter and $25 \mathrm{~mm}$ depth. The sliced concrete was placed between saturated $5 \mathrm{M} \mathrm{NaCl}$ and $\mathrm{Ca}(\mathrm{OH})_{2}$ solutions at $20^{\circ} \mathrm{C}$. Whereas, the permeability test was applied on a concrete core of $54 \mathrm{~mm}$ diameter $\times 50 \mathrm{~mm}$ depth by recording the flow rates of air passing through the specimen at various inlet pressures. The water absorption of concrete was measured according to BS 1881: Part 208 [121] by immersing a $150 \mathrm{~mm}$ concrete cube in a $200 \mathrm{~mm}$ head of water for 10 min. In their analysis, McCarthy and Dhir [120] found an enhanced durability performance of FA concrete over the CC in all tests, but for carbonation depth, the performance of FA concrete was similar to that of $\mathrm{CC}$, although, at low design strength, the FA concrete could result in more unsatisfactory performance.

Hossain and Lachemi [122] investigated the suitability of high content of volcanic ash (VA) up to $75 \%$ on the strength and durability properties and noticed that compared to the control mix, the drying shrinkage (DS) of VA mixes was slightly lower, however, all mixes experienced less than 600 micro-strains of DS. Moreover, increasing the VA content up to $40 \%$ showed a decreased 91-day permeability from $2.23 \times 10^{-10}$ to $1.58 \times 10^{-10} \mathrm{~cm} / \mathrm{s}$. Also, all VA mixes recorded a chloride ion resistance of 1000 to 3000 Coulombs, which according to ASTM C1202 [123] were classified as low to moderate chloride ion penetrability. The mix with VA beyond $40 \%$ was not recommended as it caused a sharp drop in compressive strength.

Kim et al. [124] investigated the durability of concrete while incorporating $0 \%, 5 \%$, $10 \%, 15 \%$, and $20 \%$ of MK and SF. Properties such as chloride ion permeability was reduced 
as the proportions of MK and SF were increased. Up to 300 cycles of freezing and thawing applied as per ASTM C666 [125], the relative dynamic elastic modulus of concrete mixes with $0 \%$ to $10 \% \mathrm{MK}$ or SF remain constant. The resistance of concrete to carbonation was assessed by subjecting concrete to accelerated conditions involves $5 \% \mathrm{CO}_{2}, 30^{\circ} \mathrm{C}$, and $60 \%$ relative humidity for $7,14,28$, and 56 days. Regardless of admixture type (MK or SF) in concrete, the carbonation depth was higher than that of the control mix (with no FA and SF) at all ages of the test from 7 to 56 days. When assessing the sulfuric acid attack of $2 \%$ acid solution for 56 days, the authors found a $20 \%$ reduction in compressive strength of mortar specimens with $15 \%$ MK or SF compared to the control mix.

Hossain and Lachemi [126] replaced the OPC by $5 \%, 10 \%, 15 \%$, and $20 \%$ of VA to assess concrete's durability. Their analysis demonstrated higher resistance of all VA mixes against chloride diffusion than the control concrete with $0 \%$ of VA. This observation was also confirmed by performing differential scanning calorimetry tests, which revealed less $\mathrm{Ca}(\mathrm{OH})_{2}$ content in all VA mixes than the control mix. This indicated that the $\mathrm{Ca}(\mathrm{OH})_{2}$ was consumed due to the pozzolanic reaction and as a result, created a denser microstructure with very low permeability.

Berndt [127] studied the effect of combining the partial replacement of OPC and NCA with SCM and RCA, respectively. In their results, concrete mix with either NCA or RCA was best performed in terms of mechanical and durability behavior when $50 \%$ of cement was replaced with GGBFS. Also, the presence of GGBFS in recycled concrete has decreased the coefficient of chloride diffusion, however, this coefficient along with the permeability coefficient was increased when FA and RCA were employed. In a similar investigation by Kou and Poon [128], concrete mixes with $0 \%, 50 \%$, and 100\% of RCA were prepared. In these mixes, the authors also incorporated FA at different percentages of $25 \%, 35 \%$, and $55 \%$ to evaluate their long-term (10 years) performance in terms of mechanical and durability characteristics. During this period, the concrete specimens were either cured by water or air. The control mixes with NCA have shown higher compressive strength than the recycled concretes at all ages, but this difference was noticed to decrease with the increase in the curing time. Although the recycled concrete had a more permeable structure than the control specimens, the incorporation of FA has led to a significant enhancement in the chloride ion penetration resistance. As the RCA and FA contents were increased, the carbonation coefficient increased. In general, the authors concluded that the optimal concrete mix was that with 50\% RCA and 25\% FA. In a more recent study, Faella et al. [129] combined the use of RCA with FA in concrete to investigate its durability performance and found that although the addition of RCA induced lower resistance to chloride-ion penetration due to high porosity of RCA, the addition of FA can achieve a significant attenuation of this phenomena.

Sabet et al. [130] measured the effect of FA and SF on the chloride permeability, electric resistivity, and water absorption of concrete. After 90 days of exposure to sodium chloride $(\mathrm{NaCl})$ solution, their analysis showed that the incorporation of $10 \%$ and $20 \% \mathrm{FA}$ caused a reduction in the chloride diffusion coefficient from $7.9 \times 10^{-12}$ to $4.7 \times 10^{-12}$ and $3.2 \times 10^{-12} \mathrm{~m} / \mathrm{s}^{2}$, respectively. For concrete with $10 \% \mathrm{SF}$, the chloride diffusion coefficient was reduced to $5.6 \times 10^{-12} \mathrm{~m} / \mathrm{s}^{2}$. In addition, the $10 \%$ and $20 \%$ FA concrete enhanced the electrical resistivity from $8.4 \mathrm{k} \Omega \mathrm{cm}$ in the control mix to 30 and $50 \mathrm{k} \Omega \mathrm{cm}$, respectively. However, the $10 \%$ and $20 \%$ SF concrete resulted in the most significant enhancement with 54 and $231 \mathrm{k} \Omega \mathrm{cm}$ respectively, where $\mathrm{k} \Omega$ refers to kilo-ohms. Moreover, the final absorption of water was reduced by $20 \%$ and $39 \%$ when $10 \%$ of FA and $10 \%$ of SF was incorporated in concrete, respectively.

Chousidis et al. [131] employed lower replacement levels of FA, namely, $5 \%$ and $10 \%$, to partially replace the OPC in RC specimens. These specimens were immersed for 130 days in a $3.5 \% \mathrm{NaCl}$ solution to investigate their mechanical and durability characteristics. In terms of durability, the FA mixes' sorptivity and capillary absorption were decreased in comparison with the 100\% OPC concrete. Moreover, the mass loss of steel reinforcement embedded in 5\% FA mortar was measured theoretically to be equal to that of the control 
concrete after 13 months of exposure to $\mathrm{NaCl}$. In terms of mechanical properties, the compressive strength and elastic modulus at 100 and 130 days were higher in the FA mixes due to the increased density caused by the formation of additional C-S-H.

Singh et al. [132] examined the durability effect of $3 \%$ incorporation of silica nanoparticles (SNPs) into concrete mixes having 30\% to 50\% FA. The main durability parameters were the sulfate attack and the carbonation depth, both were applied for 28, 90, and 180 days. The sulfate attack test was carried out according to ASTM C1012 [133] by slicing prisms of size $100 \mathrm{~mm} \times 100 \mathrm{~mm} \times 500 \mathrm{~mm}$ into $50 \mathrm{~mm} \times 100 \mathrm{~mm} \times 100 \mathrm{~mm}$ and immersing them inside a solution with $5 \%$ magnesium sulfate. The carbonation depth test was applied in accordance with the recommendations of RILEM CPC-18 [134] on specimen size of $100 \mathrm{~mm}$ $\times 100 \mathrm{~mm} \times 500 \mathrm{~mm}$. The specimens were placed in a $2 \% \mathrm{CO}_{2}$ concentration chamber with $65 \%$ relative humidity and a temperature of $20^{\circ} \mathrm{C}$. In comparison to concrete with $30 \%$ of FA, the incorporation of $3 \%$ of SNPs in a $30 \%$ FA concrete has reduced the carbonation depth and the sulfate attack by $73 \%$ and $39 \%$ respectively, while a $35 \%$ and a $30 \%$ reduction was observed with the incorporation of $6 \% \mathrm{SF}$, respectively.

Wang et al. [135] investigated the durability characteristics of concrete, containing SF at $5 \%, 8 \%$, and $11 \%$, and $\mathrm{FA}$ at $10 \%, 15 \%$, and $25 \%$ by weight to replace the OPC, under the combined effect of sulfate attack and freezing-thawing cycles. Prismatic concrete specimens with a size of $100 \mathrm{~mm} \times 100 \mathrm{~mm} \times 400 \mathrm{~mm}$ were immersed in $5 \%$ and $10 \%$ sodium sulfate solutions and then exposed to 175 freezing-thawing cycles. Conforming to ASTM C666 [125], one freezing and thawing cycle involved $6 \mathrm{~h}, 3 \mathrm{~h}$ for freezing at $-18 \pm 2{ }^{\circ} \mathrm{C}$, and $3 \mathrm{~h}$ for thawing at $5 \pm 2{ }^{\circ} \mathrm{C}$ in water. The test results indicated significant improvement in concrete durability for concrete with FA up to $25 \%$ and $5 \%$ to $8 \%$ SF. More freezing and thawing cycles (300 cycles) were applied by Uysal and Akyuncu [136] on concrete mixes having $10 \%$ to $17 \%$ FA as a replacement to the OPC. The results indicated no dramatic change in the weight of specimens, however, the weight loss in FA mixtures was greater than that in the control mix with no FA. The authors also observed a $5.38 \%$ to $29.83 \%$ loss in the flexural strength of specimens containing FA compared to the control specimens with $100 \%$ OPC.

\subsection{Structural Performance of GC in Large-Scale RC Beams \\ 3.5.1. Partially Replacing OPC with SCM}

As discussed in the previous sections, the compressive strength of GC has been analyzed by many studies; however, only a limited number of studies were published on its structural behavior. For example, Yoo et al. [137] evaluated the effect of high volume FA (HVFA) with a $35 \%$ and $50 \%$ replacement ratio of OPC on the flexural behavior of RC beams. Their results have shown a quasi-similar behavior to the RC members without FA in terms of cracking load, ultimate load, yielding load, and strain, however, results have shown slightly lower elastic modulus and higher mid-span deflection in HVFA beams than the control beams without FA. This could be justified by the known $25 \%$ lower density of FA than the cement material, which results in a 2 to $3 \%$ reduction in concrete's unit weight. A similar observation was noticed by Hashmi et al. [138] where the ultimate and yielding state of RC beams with $60 \%$ FA were identical to the RC beams without FA, but the RC beams with FA have demonstrated higher deflection and strain values which were attributed to the lower elastic modulus and splitting tensile strength of FA concrete. Sangeetha and Joanna [139] observed that the moment capacity in RC beams with a $40 \%$ replacement ratio of GGBFS was comparable to that of the control RC beams without GGBFS at 28 days, however, interestingly it was increased by $21 \%$ at 56 days. This could be justified by the enhanced durability [139-141] and corrosion resistance [142-144] resulted from the fine glassy shape particles of GGBFS, which reduces chloride-ion permeability, and increases the bond between particles [145-149]. Also, Sangeetha and Joanna [139] reported that the crack width at service loads was found to be in the range of 0.17 to $0.2 \mathrm{~mm}$, which is within the limits specified by IS 456-2000 [150]. A more recent study by Hawileh et al. [151] involved a higher replacement level of GGBFS by $70 \%$ and $90 \%$. Their 
results have shown a reduction in the strength and stiffness of beams with $90 \%$ of GGBFS by $6 \%$ and $16 \%$, respectively, but those beams with $50 \%$ and $70 \%$ of GGBFS were found practical and increased the ultimate load capacity by $3 \%$ and $9 \%$, respectively. Although $90 \%$ of GGBFS had sacrifices the flexural strength and stiffness to a small degree, it has increased the RC beams ductility.

On the other hand, the shear behavior of RC beams when $50 \%$ of OPC was replaced by FA was studied by Rao et al. [152]. Their experimental findings have shown a slightly lower shear strength of the FA beams than the conventional concrete (CC) beams. On the contrary, Arezoumandi and Volz [153] tested 12 full-scale beams with two FA contents by weight (50\% and 70\%) and stated that the FA beams were virtually identical to the CC beams in terms of cracking load, load-deflection diagram, and failure mode, however, beams with FA were noticed to exceed the code-predicted shear capacities by a higher margin than the beams without FA. This could be attributed to the higher fracture energy formed in the cementitious matrix of FA than the conventional OPC. Alghazali and Myers [142] investigated the shear behavior of large-scale beams with three replacement levels of FA by weight $(50 \%, 60 \%$, and $70 \%)$ and two different longitudinal reinforcement ratios $\rho(1.59 \%$ and $2.71 \%$ ). The FA beams exhibited higher shear strength than the CC ones at a lower $\rho$ of $1.59 \%$, whereas no obvious increase in the ultimate shear capacity was observed at higher $\rho$ of $2.71 \%$ but the diagonal shear crack propagation was delayed between 10 to $24 \%$. This observation is referred to the use of a small aggregate size of $10 \mathrm{~mm}$ which decreases the crack surface's roughness and minimizes the effect of the longitudinal reinforcement to prevent slippage.

\subsubsection{Partially Replacing NCA with RCA}

Central to the entire discipline of sustainable construction is the concept of utilizing RCA in RC structures. In China, the RCA concrete was successfully implemented at various pavements and building structures [154]. Hoffmann et al. [155] have also highlighted that the RCA was suitably used in a wide variety of reinforced concrete members. Numerous studies have attempted to relate the inferior properties of RCA concrete to the weak interfacial transition zone between the recycled aggregate and the new cement paste [156-163], which is mainly attributed to the old layer of mortar adhered to the surface of aggregate [164] that is characterized by loose, porous and micro-cracked surface [159,165]. In their study Han et al. [166] stated that the RC beams with 100\% RCA showed larger deflection and less shear strength than the control beams with virgin aggregate. However, Al Mahmoud [167] reported similar shear behavior of the RCA beams compared to the NCA beams in terms of the load-deflection diagram. González-Fonteboa and MartínezAbella [168] have investigated the shear behavior of recycled concrete with 50\% RCA and highlighted little differences in terms of midspan deflection and ultimate load capacity. However, notable splitting cracks and premature cracking were observed along the tension reinforcement of the recycled concrete beams. Etxeberria et al. [169] explored the possibility of implementing the RCA as a structural material in RC beams by replacing the virgin aggregates by $25 \%, 50 \%$, and $100 \%$ of RCA. The beam specimens with $50 \%$ and $100 \%$ of RCA demonstrated similar shear capacity as the control beams with $0 \%$ of RCA, but a reduction of $13 \%$ was observed for beams with $25 \%$ of RCA. Also, it was noticed that the addition of RCA has reduced the cracking load due to the occurrence of cracking at the weakest point which is the adhered mortar on the surface of RCA. Fathifazl et al. [170] observed that the shear capacity of recycled RC beams with $64 \%$ and $74 \%$ replacement level of RCA tended to increase at lower shear span to depth $\left(a_{s} / d\right)$ ratio as a result of the arch action mechanism. Furthermore, Fathifazl et al. [170] observed that the shear capacity tended to increase when the overall depth of the beam was decreased. These two observations indicated that the recycled RC beams conformed well to the known behavior of conventional RC beams. Knaack and Kurama [171] prepared two types of recycled concrete mixes, one with $50 \%$ of RCA, and one with $100 \%$ of RCA. These mixes were utilized in full-scale RC beams to investigate their flexural and shear behavior. The 
tested beams exhibited lower initial stiffness and higher ultimate flexural deflection as the RCA replacement level was increased, whereas a relatively small change in the shear and flexural strength was noticed in comparison to the conventional beams with NCA. Arezoumandi et al. [172] undertaken an experimental work that investigates the shear behavior of RC beams where the NCA was totally replaced with RCA. What was emerged from this study is that the beams with $100 \%$ RCA were virtually identical to the CC beams in terms of load deflection response, crack progression, and crack morphology.

\subsection{Comparing the Experimental Shear Capacities with Major Design Code Provisions}

The available RC design codes; in the design process of an RC beam; specify certain limits on the flexural reinforcement quantity to resist the applied moment first, and to ensure a gradual flexural failure second. However, this is not the case for failure under shear, which usually behaves in a brittle manner with little or without prior warning. Consequently, it is important to analytically investigate the ability of major RC design codes in predicting the experimental concrete shear capacity $\left(V_{\mathrm{c}}\right)$ of RC beams; where NCA and OPC are replaced with RCA and SCMs, respectively.

In this section, the concrete shear capacity will be evaluated according to several design codes namely, AASHTO LRFD-2012 [173], ACI 318-19 [174], CSA-A23.3-14 [175], and JSCE-1997 [176] and a proposed equation by Xu et al. [177]. The simplified shear design methods are listed in Table 1. For analysis, two sets of beams were collected from the available literature [141,142,166,169-172,178-182]. The first set consisted of 35 RC beams, 28 of whom the OPC was partially replaced with SCM, while in the remaining 7 RC beams the OPC and the NCA were both replaced with SCM and RCA, respectively as can be noticed in Table 2. The second set consisted of 41 beams on which the NCA only was partially replaced with RCA (Table 3).

Table 1. Summary of code provisions and simplified shear design methods.

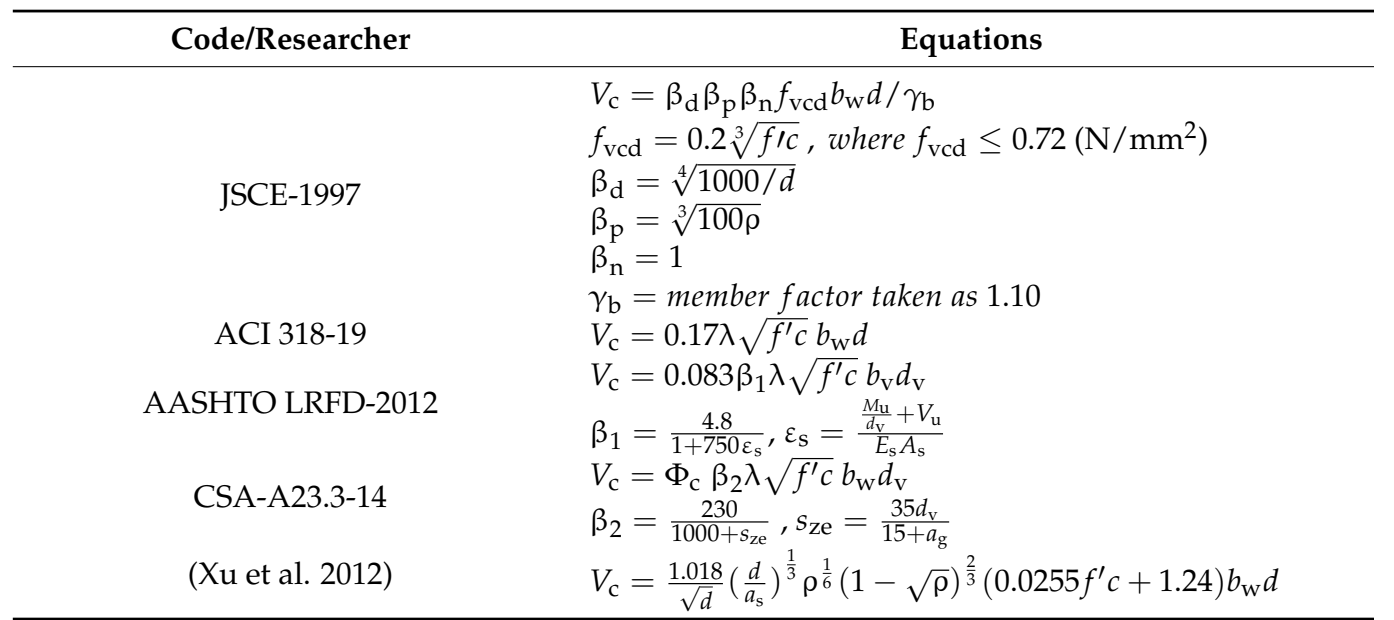

$f^{\prime} c=$ Concrete compressive strength, $b_{\mathrm{w}}=$ beam width, $d=$ beam effective depth, $\lambda=1, \beta_{1}=$ factor indicating the ability of diagonally cracked concrete to transmit tension and shear, $\varepsilon_{\mathrm{s}}=$ the longitudinal tensile strain at the centroid of the tension reinforcement, $M_{\mathrm{u}}=$ the factored moment, which should not be taken less than $V_{\mathrm{u}} d_{\mathrm{v}}$, $V_{\mathrm{u}}=$ the factored shear force, $E_{\mathrm{s}}=$ the young's modulus, $A_{\mathrm{s}}=$ the tensile reinforcement area, $b_{\mathrm{v}}=$ effective web width taken as the minimum web width between the resultants of tensile and compressive forces due to flexure, $d_{\mathrm{v}}=$ effective shear depth. It need not be less than the greater of $0.9 d$ or 0.72 times beam height (h), $\Phi_{\mathrm{c}}=$ the resistance factor for concrete. Selected as 1 in this study, $s_{\mathrm{ze}}$ is a crack spacing parameter, $a_{\mathrm{g}}=$ maximum aggregate size, $a_{\mathrm{s}}=$ shear span length of the beam. 
Table 2. Experimental and predicted shear capacities for reinforced concrete beams with partial SCM\%.

\begin{tabular}{|c|c|c|c|c|c|c|c|c|c|c|c|c|c|c|c|}
\hline \multirow[b]{2}{*}{ Source } & \multirow[b]{2}{*}{ SCM\% } & \multirow[b]{2}{*}{ RCA $\%$} & \multirow[b]{2}{*}{$\rho$} & \multirow[b]{2}{*}{$b_{\mathrm{w}}(\mathrm{mm})$} & \multirow[b]{2}{*}{$h(\mathrm{~mm})$} & \multirow[b]{2}{*}{$d(\mathrm{~mm})$} & \multirow[b]{2}{*}{$a_{\mathrm{g}}(\mathrm{mm})$} & \multirow[b]{2}{*}{$f c(\mathbf{M P a})$} & \multirow[b]{2}{*}{$a_{\mathrm{s}} / d$} & \multirow{2}{*}{$\begin{array}{l}\text { Experimental } \\
\text { Shear, } V_{c}(\mathbf{k N})\end{array}$} & \multicolumn{5}{|c|}{$V_{\text {exp }} / V_{\text {pred }}$} \\
\hline & & & & & & & & & & & $\begin{array}{l}\text { JSCE- } \\
1997\end{array}$ & $\begin{array}{c}\text { ACI } \\
318-19\end{array}$ & $\begin{array}{c}\text { AASHTO } \\
\text { LRFD } 2012\end{array}$ & $\begin{array}{c}\text { CSA- } \\
\text { A23.3-14 }\end{array}$ & $\begin{array}{c}\text { Xu et al } \\
\text { [177] }\end{array}$ \\
\hline \multirow{6}{*}{$\begin{array}{l}\text { Arezoumandi } \\
\text { et al. [181] }\end{array}$} & 50 (FA) & \multirow{6}{*}{-} & 0.0126 & 305 & 457 & 396 & 19 & 30.7 & 3.0 & 127 & 1.36 & 1.12 & 0.70 & 1.16 & 1.04 \\
\hline & 50 (FA) & & 0.0126 & 305 & 457 & 396 & 19 & 20.7 & 3.0 & 134.1 & 1.63 & 1.44 & 0.92 & 1.49 & 1.26 \\
\hline & 50 (FA) & & 0.0199 & 305 & 457 & 375 & 19 & 30.7 & 3.2 & 163.9 & 1.56 & 1.52 & 0.91 & 1.56 & 1.33 \\
\hline & 50 (FA) & & 0.0199 & 305 & 457 & 375 & 19 & 20.7 & 3.2 & 133.7 & 1.46 & 1.51 & 0.86 & 1.55 & 1.25 \\
\hline & 50 (FA) & & 0.0266 & 305 & 457 & 375 & 19 & 30.7 & 3.2 & 164.8 & 1.43 & 1.53 & 0.85 & 1.57 & 1.30 \\
\hline & 50 (FA) & & 0.0266 & 305 & 457 & 375 & 19 & 20.7 & 3.2 & 163.7 & 1.62 & 1.85 & 1.03 & 1.90 & 1.48 \\
\hline \multirow{9}{*}{$\begin{array}{l}\text { Arezoumandi } \\
\text { et al. [182] }\end{array}$} & 70 (FA) & \multirow{9}{*}{-} & 0.0157 & 305 & 457 & 396 & 19 & 22 & 3.0 & 140.7 & 1.56 & 1.46 & 0.88 & 1.52 & 1.26 \\
\hline & 70 (FA) & & 0.0199 & 305 & 457 & 375 & 19 & 22 & 3.2 & 131.9 & 1.41 & 1.45 & 0.82 & 1.48 & 1.21 \\
\hline & 70 (FA) & & 0.0266 & 305 & 457 & 375 & 19 & 22 & 3.2 & 170.9 & 1.66 & 1.87 & 1.05 & 1.92 & 1.52 \\
\hline & 70 (FA) & & 0.0266 & 305 & 457 & 375 & 19 & 21.6 & 3.2 & 162.9 & 1.59 & 1.80 & 1.00 & 1.85 & 1.45 \\
\hline & 70 (FA) & & 0.0252 & 305 & 457 & 396 & 19 & 30.7 & 3.0 & 134.3 & 1.14 & 1.18 & 0.63 & 1.23 & 1.02 \\
\hline & 70 (FA) & & 0.0252 & 305 & 457 & 396 & 19 & 20.7 & 3.0 & 122.8 & 1.19 & 1.31 & 0.69 & 1.37 & 1.07 \\
\hline & 70 (FA) & & 0.0266 & 305 & 457 & 375 & 19 & 30.7 & 3.2 & 150.4 & 1.30 & 1.40 & 0.76 & 1.43 & 1.19 \\
\hline & 70 (FA) & & 0.0266 & 305 & 457 & 375 & 19 & 20.7 & 3.2 & 168.1 & 1.66 & 1.90 & 1.06 & 1.95 & 1.52 \\
\hline & 70 (FA) & & 0.0266 & 305 & 457 & 375 & 19 & 30.7 & 3.2 & 162.4 & 1.41 & 1.51 & 0.84 & 1.54 & 1.28 \\
\hline \multirow{9}{*}{$\begin{array}{c}\text { Alghazali } \\
\text { and Myers } \\
\text { [142] }\end{array}$} & 50 (FA) & \multirow{9}{*}{-} & 0.0157 & 305 & 457 & 396 & 25 & 53.5 & 3.1 & 149.2 & 1.29 & 0.99 & 0.61 & 0.99 & 0.93 \\
\hline & 50 (FA) & & 0.0199 & 305 & 457 & 375 & 25 & 53.5 & 3.3 & 143.8 & 1.19 & 1.01 & 0.58 & 0.99 & 0.91 \\
\hline & 50 (FA) & & 0.0266 & 305 & 457 & 375 & 25 & 53.5 & 3.3 & 144 & 1.09 & 1.01 & 0.55 & 0.99 & 0.89 \\
\hline & 60 (FA) & & 0.0157 & 305 & 457 & 396 & 25 & 45.9 & 3.1 & 142.5 & 1.24 & 1.02 & 0.62 & 1.02 & 0.96 \\
\hline & 60 (FA) & & 0.0199 & 305 & 457 & 375 & 25 & 45.9 & 3.3 & 175.7 & 1.47 & 1.33 & 0.82 & 1.31 & 1.21 \\
\hline & $60(\mathrm{FA})$ & & 0.0266 & 305 & 457 & 375 & 25 & 45.9 & 3.3 & 150.6 & 1.14 & 1.14 & 0.62 & 1.12 & 1.00 \\
\hline & 70 (FA) & & 0.0157 & 305 & 457 & 396 & 25 & 52.9 & 3.1 & 146.6 & 1.26 & 0.98 & 0.60 & 0.98 & 0.92 \\
\hline & 70 (FA) & & 0.0199 & 305 & 457 & 375 & 25 & 52.9 & 3.3 & 162.2 & 1.35 & 1.15 & 0.69 & 1.13 & 1.04 \\
\hline & 70 (FA) & & 0.0266 & 305 & 457 & 375 & 25 & 52.9 & 3.3 & 154.7 & 1.17 & 1.09 & 0.60 & 1.07 & 0.96 \\
\hline \multirow{3}{*}{$\begin{array}{c}\text { Sadati et al. } \\
\text { [178] }\end{array}$} & 50 (FA) & 50 & 0.0126 & 305 & 460 & 396 & 25 & 30.8 & 3.0 & 120.5 & 1.29 & 1.06 & 0.65 & 1.05 & 0.99 \\
\hline & 50 (FA) & 50 & 0.0199 & 305 & 460 & 375 & 25 & 30.8 & 3.2 & 140.8 & 1.34 & 1.30 & 0.75 & 1.28 & 1.15 \\
\hline & 50 (FA) & 50 & 0.0266 & 305 & 460 & 375 & 25 & 30.8 & 3.2 & 136.3 & 1.18 & 1.26 & 0.68 & 1.24 & 1.07 \\
\hline \multirow{3}{*}{$\begin{array}{l}\text { Lisantono } \\
\text { et al. [182] }\end{array}$} & 50 (FA) & \multirow[t]{3}{*}{-} & 0.0106 & 150 & 260 & 214 & 25 & 15.3 & 3.5 & 57.3 & 2.64 & 2.68 & 2.24 & 2.36 & 1.73 \\
\hline & 60 (FA) & & 0.0947 & 150 & 260 & 214 & 25 & 13.7 & 3.5 & 48.9 & 1.13 & 2.42 & 1.13 & 2.12 & 1.25 \\
\hline & 70 (FA) & & 0.0947 & 150 & 260 & 214 & 25 & 11.7 & 3.5 & 41.9 & 1.02 & 2.24 & 1.03 & 1.97 & 1.11 \\
\hline
\end{tabular}


Table 2. Cont.

\begin{tabular}{|c|c|c|c|c|c|c|c|c|c|c|c|c|c|c|c|}
\hline \multirow[b]{2}{*}{ Source } & \multirow{2}{*}{ SCM\% } & \multirow{2}{*}{ RCA $\%$} & \multirow[b]{2}{*}{$\rho$} & \multirow{2}{*}{$b_{\mathrm{w}}(\mathrm{mm})$} & \multirow{2}{*}{$h(\mathrm{~mm})$} & \multirow{2}{*}{$d(\mathrm{~mm})$} & \multirow{2}{*}{$a_{\mathrm{g}}(\mathrm{mm})$} & \multirow{2}{*}{$f c(\mathrm{MPa})$} & \multirow[b]{2}{*}{$a_{\mathrm{s}} / d$} & \multirow{2}{*}{$\begin{array}{c}\text { Experimental } \\
\text { Shear, } V_{\mathrm{c}}(\mathrm{kN})\end{array}$} & \multicolumn{5}{|c|}{$V_{\text {exp }} / V_{\text {pred }}$} \\
\hline & & & & & & & & & & & $\begin{array}{l}\text { JSCE- } \\
1997\end{array}$ & $\begin{array}{c}\mathrm{ACI} \\
318-19\end{array}$ & $\begin{array}{c}\text { AASHTO } \\
\text { LRFD } 2012\end{array}$ & $\begin{array}{c}\text { CSA- } \\
\text { A23.3-14 }\end{array}$ & $\begin{array}{c}\text { Xu et al } \\
{[177]}\end{array}$ \\
\hline \multirow{4}{*}{$\begin{array}{c}\text { Sunayana } \\
\text { and Barai } \\
{[141]}\end{array}$} & 20 (FA) & 100 & 0.0038 & 200 & 300 & 267 & 20 & 47.26 & 2.6 & 82.15 & 2.33 & 1.32 & 1.86 & 1.23 & 1.16 \\
\hline & 30 (FA) & 100 & 0.0038 & 200 & 300 & 267 & 20 & 45.55 & 2.6 & 81.8 & 2.35 & 1.34 & 1.88 & 1.25 & 1.18 \\
\hline & 20 (FA) & 100 & 0.0074 & 200 & 300 & 267 & 20 & 46.11 & 2.6 & 101.72 & 2.33 & 1.65 & 1.73 & 1.55 & 1.33 \\
\hline & 30 (FA) & 100 & 0.0074 & 200 & 300 & 267 & 20 & 47.6 & 2.6 & 87.49 & 1.98 & 1.40 & 1.35 & 1.31 & 1.13 \\
\hline Mean & - & - & - & - & - & - & - & - & - & - & 1.51 & 1.47 & 0.95 & 1.45 & 1.20 \\
\hline SD & - & - & - & - & - & - & - & - & - & - & 0.40 & 0.42 & 0.41 & 0.38 & 0.22 \\
\hline $\mathrm{COV} \%$ & - & - & - & - & - & - & - & - & - & - & 26.35 & 28.72 & 42.78 & 26.30 & 18.61 \\
\hline
\end{tabular}

Table 3. Experimental and predicted shear capacities for reinforced concrete beams with partial or total RCA\%.

\begin{tabular}{|c|c|c|c|c|c|c|c|c|c|c|c|c|c|c|}
\hline \multirow[b]{2}{*}{ Source } & \multirow[b]{2}{*}{ RCA\% } & \multirow[b]{2}{*}{$\rho$} & \multirow[b]{2}{*}{$b_{\mathrm{w}}(\mathrm{mm})$} & \multirow[b]{2}{*}{$h(\mathrm{~mm})$} & \multirow[b]{2}{*}{$d(\mathrm{~mm})$} & \multirow[b]{2}{*}{$a_{\mathrm{g}}(\mathrm{mm})$} & \multirow[b]{2}{*}{$f c(\mathrm{MPa})$} & \multirow[b]{2}{*}{$a_{\mathrm{s}} / d$} & \multirow{2}{*}{$\begin{array}{c}\text { Experimental } \\
\text { Shear, } V_{\mathrm{c}}(\mathrm{kN})\end{array}$} & \multicolumn{5}{|c|}{$V_{\text {exp }} / V_{\text {pred }}$} \\
\hline & & & & & & & & & & $\begin{array}{l}\text { JSCE- } \\
1997\end{array}$ & $\begin{array}{c}\text { ACI } \\
318-19\end{array}$ & $\begin{array}{c}\text { AASHTO } \\
\text { LRFD } 2012\end{array}$ & $\begin{array}{c}\text { CSA- } \\
\text { A23.3-14 }\end{array}$ & $\begin{array}{c}\text { Xu et al. } \\
\text { [177] }\end{array}$ \\
\hline Han et al. & 100 & 0.011 & 170 & 300 & 270 & 25 & 39.6 & 1.5 & 83.5 & 2.05 & 1.70 & 1.40 & 1.96 & 1.08 \\
\hline- & 100 & 0.011 & 170 & 300 & 270 & 25 & 30.6 & 2 & 65.2 & 1.74 & 1.51 & 1.11 & 1.53 & 1.03 \\
\hline- & 100 & 0.011 & 170 & 300 & 270 & 25 & 32.6 & 2 & 60.6 & 1.59 & 1.36 & 0.97 & 1.42 & 0.94 \\
\hline- & 100 & 0.011 & 170 & 300 & 270 & 25 & 31.2 & 3 & 42.7 & 1.13 & 0.98 & 0.62 & 1.00 & 0.77 \\
\hline- & 100 & 0.011 & 170 & 300 & 270 & 25 & 31.9 & 4 & 31.7 & 0.84 & 0.72 & 0.42 & 0.74 & 0.62 \\
\hline $\begin{array}{c}\text { Belen and } \\
\text { Fernando } \\
{[179]}\end{array}$ & 50 & 0.030 & 200 & 350 & 303 & 25 & 39.7 & 3.3 & 90.6 & 1.24 & 1.40 & 0.76 & 1.64 & 1.09 \\
\hline $\begin{array}{l}\text { Etxeberria } \\
\text { et al. [169] }\end{array}$ & 25 & 0.030 & 200 & 350 & 303 & 25 & 42.4 & 3.3 & 104 & 1.39 & 1.55 & 0.88 & 1.89 & 1.21 \\
\hline- & 50 & 0.030 & 200 & 350 & 303 & 25 & 41.3 & 3.3 & 89 & 1.20 & 1.34 & 0.73 & 1.62 & 1.05 \\
\hline- & 100 & 0.030 & 200 & 350 & 303 & 25 & 39.8 & 3.3 & 84 & 1.15 & 1.29 & 0.70 & 1.52 & 1.01 \\
\hline $\begin{array}{l}\text { Ji et al. } \\
\text { [179] }\end{array}$ & 100 & 0.012 & 170 & 300 & 270 & 20 & 39.7 & 2.2 & 60 & 1.45 & 1.22 & 0.85 & 1.61 & 0.87 \\
\hline
\end{tabular}


Table 3. Cont.

\begin{tabular}{|c|c|c|c|c|c|c|c|c|c|c|c|c|c|c|}
\hline \multirow[b]{2}{*}{ Source } & \multirow[b]{2}{*}{ RCA\% } & \multirow[b]{2}{*}{$\rho$} & \multirow[b]{2}{*}{$b_{\mathrm{w}}(\mathrm{mm})$} & \multirow[b]{2}{*}{$h(\mathrm{~mm})$} & \multirow[b]{2}{*}{$d(\mathrm{~mm})$} & \multirow[b]{2}{*}{$a_{\mathrm{g}}(\mathrm{mm})$} & \multirow{2}{*}{$f c(\mathrm{MPa})$} & \multirow[b]{2}{*}{$a_{\mathrm{s}} / d$} & \multirow{2}{*}{$\begin{array}{c}\text { Experimental } \\
\text { Shear, } V_{\mathrm{c}}(\mathrm{kN})\end{array}$} & \multicolumn{5}{|c|}{$V_{\text {exp }} / V_{\text {pred }}$} \\
\hline & & & & & & & & & & $\begin{array}{l}\text { JSCE- } \\
1997\end{array}$ & $\begin{array}{c}\text { ACI } \\
318-19\end{array}$ & $\begin{array}{l}\text { AASHTO } \\
\text { LRFD } 2012\end{array}$ & $\begin{array}{c}\text { CSA- } \\
\text { A23.3-14 }\end{array}$ & $\begin{array}{c}\text { Xu et al. } \\
\text { [177] }\end{array}$ \\
\hline $\begin{array}{l}\text { Fathifazl } \\
\text { et al. [170] }\end{array}$ & 63.5 & 0.010 & 200 & 375 & 300 & 19 & 41.6 & 1.5 & 186.7 & 3.60 & 2.84 & 3.24 & 4.06 & 1.91 \\
\hline- & 63.5 & 0.016 & 200 & 375 & 300 & 19 & 41.6 & 2 & 169.5 & 2.85 & 2.58 & 2.21 & 3.69 & 1.82 \\
\hline - & 63.5 & 0.014 & 200 & 375 & 309 & 19 & 41.6 & 2.7 & 103.9 & 1.77 & 1.53 & 1.09 & 2.21 & 1.23 \\
\hline- & 63.5 & 0.026 & 200 & 375 & 305 & 19 & 41.6 & 4 & 83.2 & 1.17 & 1.24 & 0.69 & 1.79 & 1.06 \\
\hline- & 74.3 & 0.010 & 200 & 375 & 300 & 19 & 49.1 & 1.5 & 195.3 & 3.62 & 2.73 & 3.21 & 4.25 & 1.85 \\
\hline- & 74.3 & 0.026 & 200 & 375 & 305 & 19 & 49.1 & 4 & 105.6 & 1.43 & 1.45 & 0.86 & 2.27 & 1.24 \\
\hline- & 63.5 & 0.013 & 200 & 250 & 201 & 19 & 41.6 & 2.7 & 89.3 & 2.15 & 2.03 & 1.69 & 2.67 & 1.32 \\
\hline- & 63.5 & 0.014 & 200 & 375 & 309 & 19 & 41.6 & 2.6 & 103.9 & 1.77 & 1.53 & 1.09 & 2.21 & 1.21 \\
\hline- & 63.5 & 0.018 & 200 & 450 & 381 & 19 & 41.6 & 2.7 & 99.5 & 1.35 & 1.19 & 0.72 & 1.81 & 1.03 \\
\hline- & 63.5 & 0.017 & 200 & 550 & 476 & 19 & 41.6 & 2.7 & 104.6 & 1.22 & 1.00 & 0.58 & 1.63 & 0.98 \\
\hline- & 74.3 & 0.020 & 200 & 250 & 201 & 19 & 49.1 & 2.7 & 122.6 & 2.48 & 2.56 & 2.03 & 3.67 & 1.59 \\
\hline- & 74.3 & 0.018 & 200 & 450 & 381 & 19 & 49.1 & 2.7 & 111.7 & 1.46 & 1.23 & 0.77 & 2.04 & 1.07 \\
\hline- & 74.3 & 0.017 & 200 & 550 & 476 & 19 & 49.1 & 2.7 & 119.6 & 1.34 & 1.05 & 0.64 & 1.87 & 1.03 \\
\hline \multicolumn{15}{|l|}{ Knaack and } \\
\hline- & 50 & 0.0134 & 150 & 230 & 200 & 19 & 41.8 & 3.8 & 39.1 & 1.25 & 1.19 & 0.78 & 1.57 & 0.86 \\
\hline- & 50 & 0.0134 & 150 & 230 & 200 & 19 & 37.4 & 3.8 & 43.7 & 1.45 & 1.40 & 0.96 & 1.75 & 1.01 \\
\hline- & 50 & 0.0134 & 150 & 230 & 200 & 19 & 37.4 & 3.8 & 41.2 & 1.37 & 1.32 & 0.89 & 1.65 & 0.96 \\
\hline- & 100 & 0.0134 & 150 & 230 & 200 & 19 & 39.1 & 3.8 & 36.4 & 1.19 & 1.14 & 0.74 & 1.46 & 0.83 \\
\hline- & 100 & 0.0134 & 150 & 230 & 200 & 19 & 39.1 & 3.8 & 38 & 1.24 & 1.19 & 0.78 & 1.52 & 0.86 \\
\hline- & 100 & 0.0134 & 150 & 230 & 200 & 19 & 39.2 & 3.8 & 39.9 & 1.31 & 1.25 & 0.83 & 1.60 & 0.91 \\
\hline- & 100 & 0.0134 & 150 & 230 & 200 & 19 & 39.2 & 3.8 & 36.1 & 1.18 & 1.13 & 0.73 & 1.45 & 0.82 \\
\hline $\begin{array}{l}\text { Arezoumandi } \\
\text { et al. [172] }\end{array}$ & 100 & 0.0125 & 305 & 460 & 400 & 25 & 30 & 3.1 & 114.8 & 1.23 & 1.01 & 0.61 & 1.10 & 0.96 \\
\hline- & 100 & 0.0199 & 305 & 460 & 375 & 25 & 30 & 3.25 & 143.2 & 1.38 & 1.34 & 0.78 & 1.45 & 1.18 \\
\hline- & 100 & 0.0266 & 305 & 460 & 375 & 25 & 30 & 3.25 & 131.4 & 1.15 & 1.23 & 0.65 & 1.33 & 1.05 \\
\hline- & 100 & 0.0125 & 305 & 460 & 400 & 25 & 34.1 & 3.1 & 113 & 1.16 & 0.93 & 0.57 & 1.09 & 0.89 \\
\hline- & 100 & 0.0199 & 305 & 460 & 375 & 25 & 34.1 & 3.25 & 124.1 & 1.14 & 1.09 & 0.61 & 1.25 & 0.97 \\
\hline- & 100 & 0.0266 & 305 & 460 & 375 & 25 & 34.1 & 3.25 & 140.3 & 1.18 & 1.24 & 0.66 & 1.42 & 1.07 \\
\hline
\end{tabular}


Table 3. Cont.

\begin{tabular}{|c|c|c|c|c|c|c|c|c|c|c|c|c|c|c|}
\hline \multirow[b]{2}{*}{ Source } & \multirow[b]{2}{*}{ RCA\% } & \multirow[b]{2}{*}{$\rho$} & \multirow[b]{2}{*}{$b_{\mathrm{w}}(\mathrm{mm})$} & \multirow[b]{2}{*}{$h(\mathrm{~mm})$} & \multirow[b]{2}{*}{$d(\mathrm{~mm})$} & \multirow[b]{2}{*}{$a_{\mathrm{g}}(\mathrm{mm})$} & \multirow{2}{*}{$f c(\mathrm{MPa})$} & \multirow[b]{2}{*}{$a_{\mathrm{s}} / d$} & \multirow{2}{*}{$\begin{array}{c}\text { Experimental } \\
\text { Shear, } V_{\mathrm{c}}(\mathrm{kN})\end{array}$} & \multicolumn{5}{|c|}{$V_{\text {exp }} / V_{\text {pred }}$} \\
\hline & & & & & & & & & & $\begin{array}{l}\text { JSCE- } \\
1997\end{array}$ & $\begin{array}{c}\text { ACI } \\
318-19\end{array}$ & $\begin{array}{c}\text { AASHTO } \\
\text { LRFD } 2012\end{array}$ & $\begin{array}{c}\text { CSA- } \\
\text { A23.3-14 }\end{array}$ & $\begin{array}{c}\text { Xu et al. } \\
\text { [177] }\end{array}$ \\
\hline $\begin{array}{c}\text { Sadati et al. } \\
\text { [178] }\end{array}$ & 50 & 0.013 & 305 & 460 & 396 & 25 & 32 & 3.0 & 117.4 & 1.24 & 1.01 & 0.62 & 1.14 & 0.95 \\
\hline- & 50 & 0.020 & 305 & 460 & 375 & 25 & 32 & 3.2 & 151.2 & 1.42 & 1.37 & 0.81 & 1.53 & 1.21 \\
\hline- & 50 & 0.027 & 305 & 460 & 375 & 25 & 32 & 3.2 & 171.7 & 1.47 & 1.56 & 0.88 & 1.73 & 1.33 \\
\hline Mean & - & - & - & - & - & - & - & - & - & 1.58 & 1.45 & 1.03 & 1.90 & 1.11 \\
\hline SD & - & - & - & - & - & - & - & - & - & 0.63 & 0.50 & 0.65 & 0.83 & 0.29 \\
\hline COV\% & - & - & - & - & - & - & - & - & - & 40.20 & 34.62 & 62.53 & 43.95 & 26.34 \\
\hline
\end{tabular}


In reviewing the literature, no data was found on the shear behavior of RC beams with GGBFS, SF, or MK as a cement component. On the other hand, several studies have investigated the shear behavior of large-scale RC beams while utilizing FA as a partially replacing material to the OPC, as summarized in Table 2.

Before analyzing the prediction accuracy of each design model, the various models in Table 1 will be qualitatively compared to highlight the difference among them. It is worth noting that both models, the ACI 318-19 [174] and the CSA-A23.3-14 [175], are not considering the reinforcement ratio $(\rho)$ and the $\left(\frac{a_{\mathrm{S}}}{d}\right)$ effects on concrete shear capacity. Similarly, in JSCE-1997 [176], the $\left(\frac{a_{\mathrm{s}}}{d}\right)$ effect is not counted. In the literature, a strong relationship between the shear capacity and varying $(\rho)$ and $\left(\frac{a_{\mathrm{s}}}{d}\right)$ has been reported $[141,142,166,169-172,178-182]$. Hence, the exclusion of these variables is expected to result in inconsistent predictions. On the other hand, AASHTO LRFD-2012 [173] and the proposed equation by Xu et al. [177] have considered these effects. One source of inaccuracy in Xu et al.'s [177] model could be that the proposed equation predicts zero shear strength for concrete sections without flexural reinforcement. However, this is not a major problem since reinforcement exists in practical life applications.

As can be seen in Table 2, the replacement level of SCM with OPC is ranging between $20 \%$ to $70 \%$. The concrete shear strength models of ACI 318-19 [174], CSA-A23.3-14 [175], and JSCE-1997 [176] have shown very conservative predictions with average experimental to predicted shear capacities $\left(V_{\exp } / V_{\text {pred }}\right)$ of $1.47 \pm 0.42,1.45 \pm 0.38$, and $1.51 \pm 0.4$, respectively. The proposed model of Xu et al. [177] also reported conservative predictions but with higher accuracy, where $V_{\exp } / V_{\text {pred }}=1.2 \pm 0.22$. In addition, Xu et al.'s [177] model recorded the least coefficient of variation, $\mathrm{COV} \%=18.61$, which indicates better consistency compared to other models. On the contrary, AASHTO LRFD-2012 [173] overestimated the predictions with $V_{\text {exp }} / V_{\text {pred }}=0.95 \pm 0.41$ and COV\% of 42.78 . However, for those beams with $20 \%$ to $30 \%$ of FA, the AASHTO LRFD-2012 [173] has shown underestimated predictions.

From the data in Table 3, it is apparent that RCA\% is ranging from $25 \%$ to $100 \%$. As the above observations, Xu et al.'s [177] model revealed the most accurate predictions with $V_{\text {exp }} / V_{\text {pred }}=1.11 \pm 0.29$ and better consistency than the rest of the codes, with COV\% of 26.34. On the other hand, AASHTO LRFD-2012 [173] demonstrated the least accurate predictions with $V_{\text {exp }} / V_{\text {pred }}=1.03 \pm 0.65$ and COV\% of 62.53. The predictions of AASHTO LRFD-2012 [173] appeared to be conservative for $\left(\frac{a_{\mathrm{s}}}{d}\right)$ less than 2.7, whereas the predictions were over-estimated for $\left(\frac{a_{\mathrm{s}}}{d}\right)$ greater than 2.7. The results, as shown in Table 3 , indicate that the CSA-A23.3-14 [175] revealed the most conservative and high variability in predictions, with $V_{\text {exp }} / V_{\text {pred }}$ and COV\% of $1.90 \pm 0.83$ and 43.95, respectively. Furthermore, both the JSCE-1997 [176] and ACI 318-19 [174] predictions in Table 3 were found to be consistent with those in Table 2, with $V_{\text {exp }} / V_{\text {pred }}$ of $1.58 \pm 0.63$ and $1.45 \pm 0.50$, and COV\% of 40.20 and 34.62, respectively. As expected, the high variability in predictions accords well with our earlier qualitative comparison of the presented models in Table 1, which might be due to the exclusion of important factors such as $\rho$ and $\frac{a_{\mathrm{s}}}{d}$.

\section{Conclusions}

In this review, the sustainability benefits of GC were discussed first, then its mechanical properties when incorporating GGBFS, FA, SF, or MK as a partially replacing material for cement were analyzed at different replacement levels, different ages, and different $\mathrm{W} / \mathrm{b}$ ratios in terms of compressive strength. The durability properties of GC were discussed under different environmental exposures. Following this, the structural behavior of GC in large-scale RC beams was analyzed and their concrete shear capacities were compared analytically to the available design codes, such as JSCE-1997 [176], ACI 318- 2019 [174], AASHTO LRFD-2012 [173], and CSA-A23.3-2014 [175], and a proposed equation by $\mathrm{Xu}$ et al. [177]. Based on the above review, the main outcomes are summarized as follow: 
- The SF and MK were very effective in gaining higher early strength than the control mix with $100 \%$ OPC.

- At 90 days, the GGBFS concrete reported higher compressive strength than $40 \mathrm{MPa}$, except for concrete with $80 \%$ of GGBFS at W/b of 0.5 .

- The analysis revealed that the 28-day strength of 20 to $35 \mathrm{MPa}$ was achieved when the $\mathrm{W} / \mathrm{b}$ range of 0.5 to 0.6 or 0.24 to 0.45 is implemented with a replacement level of FA of $10 \%$ to $30 \%$ or $40 \%$ to $60 \%$, respectively.

- Higher strength grades (at 28 days) of the range 40 to $60 \mathrm{MPa}$ and 60 to $80 \mathrm{MPa}$ can be achieved when $\mathrm{W} / \mathrm{b}$ ranges are 0.27 to 0.4 and 0.24 to 0.36 and when the replacement levels of FA are $10 \%$ to $55 \%$ and $10 \%$ to $40 \%$, respectively.

- At the age of 28 days, high strength grades of the range 40 to $60 \mathrm{MPa}$ and 60 to $90 \mathrm{MPa}$ were achieved when $\mathrm{W} / \mathrm{b}$ is of the range 0.35 to 0.5 and 0.26 to 0.4 and when the replacement ratio of SF is ranging from $5 \%$ to $20 \%$ and $5 \%$ to $25 \%$, respectively.

- For concrete with MK, the 28-day strength of 60 to $80 \mathrm{MPa}$ was achieved at $\mathrm{W} / \mathrm{b}$ of 0.3 to 0.36 and with a replacement level in the range of $10 \%$ to $20 \%$. At lower $\mathrm{W} / \mathrm{b}$ of 0.27 to 0.33 , the strength range of 80 to $100 \mathrm{MPa}$ was achieved at replacement levels of $5 \%$ to $15 \%$, respectively.

- At elevated temperatures higher than $400{ }^{\circ} \mathrm{C}$, the concrete mixes with either GGBFS, $\mathrm{FA}$, or SF demonstrated a sharp reduction in compressive strength.

- The sorptivity in pozzolanic cement pastes is remarkably lower than that in Portland cement paste.

- The long-term resistance to sulfate attack of concrete that combines GGBFS and FA was observed to be superior to the CC mix and high-volume FA concrete mix. Also, the former mix experienced less change in weight.

- The carbonation depth was shown to increase with the increased content of SCMs, and regardless of SCM type in concrete, the carbonation depth was higher than that of the control mix (with no SCM).

- The incorporation of silica nanoparticles (SNPs) could result in a significant reduction in the carbonation depth and the sulfate attack.

- Although the RCA concrete had a more permeable structure than the NCA concrete, the incorporation of FA, GGBFS, or SF can lead to a significant enhancement in the chloride ion penetration resistance.

- The concrete shear strength models of JSCE-1997 [176], ACI 318-19 [174], and CSAA23.3-14 [175] have shown very conservative predictions for concrete beams with FA or RCA, whereas predictions were over-estimated by AASHTO LRFD-2012 [173].

- Among all models, the model of $\mathrm{Xu}$ et al. [177] revealed the most accurate predictions with $V_{\exp } / V_{\text {pred }}=1.2 \pm 0.22$ and $1.11 \pm 0.29$ for beams with FA or RCA, respectively.

Continued efforts are needed to determine the stress-strain behavior of GC to account for the required design considerations. In addition, further research could also be conducted to determine the GC behavior in large-scale specimens such as beams and slabs under shear and flexure, to develop an understanding of how the combination of GC, bars, and stirrups can create a system that is functional and safe. Another important aspect of research that might produce striking findings is to investigate the bond efficiency of GC with the conventional steel or with fiber-reinforced polymer (FRP) bars. On a wider level, there is a need for a holistic, detailed, and accurate social, economic, and environmental sustainability analysis of GC that considers all stages of GC product from cradle to grave. Finally, we believe that our research will serve as a base for analyzing other types of substitutes in GC, such as agricultural and municipal wastes.

Supplementary Materials: The following are available in an excel sheet online at https://www. mdpi.com/1996-1944/14/2/351/s1, Table S1: GGBFS concrete, Table S2: FA concrete, Table S3: SF concrete, Table S4: MK concrete. 
Author Contributions: Original draft preparation: A.A.-H.; Methodology A.A.-H., M.K. and W.A.; Investigation A.A.-H.; Resources: A.A.-H. and M.K.; Formal analysis A.A.-H. and M.K.; Visualization A.A.-H.; Supervision M.K. and W.A.; Review and editing A.A.-H., M.K., W.A., E.M., and N.C.O. All authors have read and agreed to the published version of the manuscript.

Funding: This research was funded by the Graduate Sponsorship Research Award (GSRA) grant number GSRA6-1-0301-19005.

Institutional Review Board Statement: Not applicable.

Informed Consent Statement: Not applicable.

Data Availability Statement: Data is contained within the article or Supplementary Material. The data presented in this study are available in Al-Hamrani, A.; Kucukvar, M.; Alnahhal, W.; Mahdi Saad, E.; Onat, N.C. Green Concrete for a Circular Economy: A Review on Sustainability, Durability, and Structural Properties.

Acknowledgments: The authors wish to express their gratitude to Qatar Foundation for their financial support through the GSRA grant no. GSRA6-1-0301-19005 from the Qatar National Research Fund (QNRF, a member of Qatar Foundation).

Conflicts of Interest: The authors declare no conflict of interest.

$\begin{array}{ll}\text { Abbreviations } \\ \text { CE } & \text { Circular economy } \\ \text { PCC } & \text { Portland cement concrete } \\ \text { C\&D } & \text { Construction and demolition } \\ \text { GC } & \text { Green concrete } \\ \text { NCA } & \text { Natural coarse aggregates } \\ \text { RCA } & \text { Recycled coarse aggregates } \\ \text { OPC } & \text { ordinary Portland cement } \\ \text { SCM } & \text { Supplementary cementitious material } \\ \text { GGBFS } & \text { Ground granulated blast furnace slag } \\ \text { FA } & \text { Fly ash } \\ \text { SF } & \text { Silica fume } \\ \text { MK } & \text { Metakaolin } \\ \text { RHA } & \text { Rice husk ash } \\ \text { LCA } & \text { Life cycle assessment } \\ \text { CC } & \text { Conventional concrete } \\ \text { EAF } & \text { Electric arc furnace } \\ \text { GWP } & \text { Global warming potential } \\ \text { C-S-H } & \text { Calcium silicate hydrate } \\ \text { RC } & \text { Reinforced concrete } \\ \text { GGFAC } & \text { Concrete with a combination of GGBFS and FA } \\ \text { VA } & \text { Volcanic ash } \\ \text { DS } & \text { Drying shrinkage } \\ \text { SNPs } & \text { Silica nanoparticles } \\ \text { HVFA } & \text { High-volume FA } \\ & \end{array}$

\section{References}

1. Blomsma, F.; Brennan, G. The Emergence of Circular Economy: A New Framing Around Prolonging Resource Productivity. J. Ind. Ecol. 2017, 21, 603-614. [CrossRef]

2. Deschamps, J.; Simon, B.; Tagnit-Hamou, A.; Amor, B. Is open-loop recycling the lowest preference in a circular economy? Answering through LCA of glass powder in concrete. J. Clean. Prod. 2018, 185, 14-22. [CrossRef]

3. Khan, A.A.; Arshad, S.; Mohsin, M. Population Growth and Its Impact on Urban Expansion: A Case Study of Population Growth and Its Impact on Urban Expansion: A Case Study of Bahawalpur, Pakistan. Univers. J. Geosci. 2014, 2, 229-241. [CrossRef]

4. Guney, T. Population Growth and Sustainable Development in Developed- Developing Countries: An Iv (2sls) Approach. J. Fac. Econ. Adm. Sci. 2017, 22, 1255-1277. 
5. Tafheem, Z.; Khusru, S.; Nasrin, S. Environmental Impact of Green Concrete in Practice ICMERE2011-PI-069. In Proceedings of the 1st International Conference on Mechanical Engineering and Renewable Energy (ICMERE), Chittagong, Bangladesh, 22-24 December 2011.

6. Marie, I.; Quiasrawi, H. Closed-loop recycling of recycled concrete aggregates. J. Clean. Prod. 2012, 37, 243-248. [CrossRef]

7. Sergeant, G.; Lerut, E.; Ectors, N.; Hendrickx, T.; Aerts, R.; Topal, B. National Ready Mixed Concrete Association (NRMCA) Concrete CO 2 Fact Sheet. Eur. J. Surg. Oncol. 2008. [CrossRef]

8. Mamlouk, M.S.; Zaniewski, J.P. Materials for Civil and Construction Engineers; Pearson Prentice Hall: Upper Saddle River, NJ, USA, 2006; ISBN 9780136110583.

9. Andrew, R.M. Global $\mathrm{CO}_{2}$ emissions from cement production. Earth Syst. Sci. Data Discuss. 2017, 195-217. [CrossRef]

10. Ahmad, S.; Kumar, A.; Kumar, K. Axial performance of GGBFS concrete filled steel tubes. Structures 2020, 23, 539-550. [CrossRef]

11. Imbabi, M.S.; Carrigan, C.; McKenna, S. Trends and developments in green cement and concrete technology. Int. J. Sustain. Built Environ. 2012, 1, 194-216. [CrossRef]

12. Karsan, K.R.; Hoseini, A.G. Investigating the Effectiveness of Using Green Concrete Towards Promotion of Sustainable Built. Univ. Putra Malays. 2015, 8, 49-59.

13. Rashad, A.M. An investigation of high-volume fl y ash concrete blended with slag subjected to elevated temperatures. J. Clean. Prod. 2015, 93, 47-55. [CrossRef]

14. Albitar, M.; Ali, M.S.M.; Visintin, P.; Drechsler, M. Effect of granulated lead smelter slag on strength of fly ash-based geopolymer concrete. Constr. Build. Mater. 2015, 83, 128-135. [CrossRef]

15. Baspinar, M.S.; Demir, I. Utilization potential of silica fume in fired clay bricks. Waste Manag. Res. 2010, 149-157. [CrossRef] [PubMed]

16. FAO. FAOSTAT Food and Agriculture Organization of the United Nations Statistic Division (FAOSTAT) Domains e Crops: Rice paddy, Production Quantity, World Total; FAO: Roman, Italy, 2012.

17. Younis, K.H.; Pilakoutas, K. Strength prediction model and methods for improving recycled aggregate concrete. Constr. Build. Mater. 2013, 49, 688-701. [CrossRef]

18. Akhtar, A.; Sarmah, A.K. Construction and demolition waste generation and properties of recycled aggregate concrete: A global perspective. J. Clean. Prod. 2018, 186, 262-281. [CrossRef]

19. Behera, M.; Bhattacharyya, S.K.; Minocha, A.K.; Deoliya, R.; Maiti, S. Recycled aggregate from C \& D waste \& its use in concrete-A breakthrough towards sustainability in construction sector: A review. Constr. Build. Mater. 2014, 68, 501-516. [CrossRef]

20. Mukharjee, B.B.; Barai, S.V. Statistical techniques to analyze properties of nano-engineered concrete using Recycled Coarse Aggregates. J. Clean. Prod. 2014, 83, 273-285. [CrossRef]

21. Tam, V.W.Y.; Soomro, M.; Catarina, A.; Evangelista, J. A review of recycled aggregate in concrete applications (2000-2017). Constr. Build. Mater. 2018, 172, 272-292. [CrossRef]

22. Yehia, S.; Helal, K.; Abusharkh, A.; Zaher, A.; Istaitiyeh, H. Strength and Durability Evaluation of Recycled Aggregate Concrete. Int. J. Concr. Struct. Mater. 2015. [CrossRef]

23. Mukharjee, B.B.; Barai, S.V. Influence of Nano-Silica on the properties of recycled aggregate concrete. Constr. Build. Mater. 2014, 55, 29-37. [CrossRef]

24. Al-mansour, A.; Chow, C.L.; Feo, L.; Penna, R.; Lau, D. Green Concrete: By-Products Utilization and Advanced Approaches. Sustainability 2019, 11, 5145. [CrossRef]

25. Suhendro, B. Toward green concrete for better sustainable environment. Procedia Eng. 2014, 95, 305-320. [CrossRef]

26. Müller, H.S.; Breiner, R.; Moffatt, J.S.; Haist, M. Design and properties of sustainable concrete. Procedia Eng. 2014, 95, 290-304. [CrossRef]

27. Badogiannis, E.; Papadakis, V.G.; Chaniotakis, E.; Tsivilis, S. Exploitation of poor Greek kaolins: Strength development of metakaolin concrete and evaluation by means of k-value. Cem. Concr. Res. 2004, 34, 1035-1041. [CrossRef]

28. Roy, D.M.; Arjunan, P.; Silsbee, M.R. Effect of silica fume, metakaolin, and low-calcium fly ash on chemical resistance of concrete. Cem. Concr. Res. 2001, 31, 1809-1813. [CrossRef]

29. Ferraris, C.F.; Obla, K.H.; Hill, R. The influence of mineral admixtures on the rheology of cement paste and concrete. Cem. Concr. Res. 2001, 31, 245-255. [CrossRef]

30. Chan, W.W.J.; Wu, C.M.L. Durability of concrete with high cement replacement. Cem. Concr. Res. 2000, 30, 865-879. [CrossRef]

31. Long, G.; Gao, Y.; Xie, Y. Designing more sustainable and greener self-compacting concrete. Constr. Build. Mater. 2015, 84, 301-306. [CrossRef]

32. Liew, K.M.; Sojobi, A.O.; Zhang, L.W. Green concrete: Prospects and challenges. Constr. Build. Mater. 2017, 156, 1063-1095. [CrossRef]

33. Ghahari, S.A.; Assi, L.N.; Alsalman, A.; Alyamaç, K.E. Fracture properties evaluation of cellulose nanocrystals cement paste. Materials 2020, 13, 2507. [CrossRef] [PubMed]

34. Knoeri, C.; Sanyé-Mengual, E.; Althaus, H.J. Comparative LCA of recycled and conventional concrete for structural applications. Int. J. Life Cycle Assess. 2013, 18, 909-918. [CrossRef]

35. Blengini, G.A.; Garbarino, E. Resources and waste management in Turin (Italy): The role of recycled aggregates in the sustainable supply mix. J. Clean. Prod. 2010, 18, 1021-1030. [CrossRef] 
36. Leising, E.; Quist, J.; Bocken, N. Circular Economy in the building sector: Three cases and a collaboration tool. J. Clean. Prod. 2018, 176, 976-989. [CrossRef]

37. Yazdanbakhsh, A.; Bank, L.C.; Baez, T.; Wernick, I. Comparative LCA of concrete with natural and recycled coarse aggregate in the New York City area. Int. J. Life Cycle Assess. 2018, 1163-1173. [CrossRef]

38. Faleschini, F.; Pellegrino, C. Recycled concrete containing EAF slag: Environmental assessment through LCA. Eur. J. Environ. Civ. Eng. 2014. [CrossRef]

39. Abbas, A.; Fathifazl, G.; Isgor, O.B.; Razaqpur, A.G.; Fournier, B.; Foo, S. Environmental benefits of green concrete. In Proceedings of the 2006 IEEE EIC Climate Change Technology Conference, EICCCC 2006, Ottawa, ON, Canada, 10-12 May 2006.

40. Shan, X.; Zhou, J.; Chang, V.W.; Yang, E. Life cycle assessment of adoption of local recycled aggregates and green concrete in Singapore perspective. J. Clean. Prod. 2017, 164, 918-926. [CrossRef]

41. Turk, J.; Cotic, Z.; Mladenovic, A.; Sajna, A. Environmental evaluation of green concretes versus conventional concrete by means of LCA. Waste Manag. 2015, 45, 194-205. [CrossRef]

42. Gursel, A.P.; Maryman, H.; Ostertag, C. A life-cycle approach to environmental, mechanical, and durability properties of "green" concrete mixes with rice husk ash. J. Clean. Prod. 2016, 112, 823-836. [CrossRef]

43. Thomas, B.S. Green concrete partially comprised of rice husk ash as a supplementary cementitious material-A comprehensive review. Renew. Sustain. Energy Rev. 2018, 82, 3913-3923. [CrossRef]

44. Flower, D.J.M.; Sanjayan, J.G. Green house gas emissions due to concrete manufacture. Int. J. Life Cycle Assess. 2007, 12, 282-288. [CrossRef]

45. Divsholi, B.S.; Yang, T.; Lim, D.; Teng, S. Durability Properties and Microstructure of Ground Granulated Blast Furnace Slag Cement Concrete. Int. J. Concr. Struct. Mater. 2014, 8, 157-164. [CrossRef]

46. Yu, J.; Mishra, D.K.; Leung, C.K.Y. Very high volume fly ash green concrete for applications in India. Waste Manag. Res. 2018, 36, 520-526. [CrossRef] [PubMed]

47. Elchalakani, M.; Aly, T.; Abu-Aisheh, E. Sustainable concrete with high volume GGBFS to build Masdar City in the UAE. Case Stud. Constr. Mater. 2014, 1, 10-24. [CrossRef]

48. Song, W.; Yi, J.; Wu, H.; He, X.; Song, Q.; Yin, J. Effect of carbon fi ber on mechanical properties and dimensional stability of concrete incorporated with granulated-blast furnace slag. J. Clean. Prod. 2019, 238, 117819. [CrossRef]

49. Sha, W.; Pereira, G.B. Differential scanning calorimetry study of hydrated ground granulated blast-furnace slag. Cem. Concr. Res. 2001, 31, 327-329. [CrossRef]

50. Oner, A.; Akyuz, S. An experimental study on optimum usage of GGBS for the compressive strength of concrete. Cem. Concr. Compos. 2007, 29, 505-514. [CrossRef]

51. American Concrete Institute. Ground Granulated Blast-Furnace Slag as a Cementitious Constituent in Concrete. ACI 233R-95; American Concrete Institute: Farmington Hills, MI, USA, 1995; pp. 1-18.

52. Yun, K.; Kyum, E. An experimental study on corrosion resistance of concrete with ground granulate blast-furnace slag Cem. Concr. Res. 2005, 35, 1391-1399. [CrossRef]

53. Khatib, J.M.; Hibbert, J.J. Selected engineering properties of concrete incorporating slag and metakaolin. Constr. Build. Mater. 2005, 19, 460-472. [CrossRef]

54. Patil, Y.O.; Patil, P.P.N.; Student, P.G.; Course, M.E.; Course, P.G. GGBS as Partial Replacement of OPC in Cement Concrete-An Experimental Study Engineering. Int. J. Sci. Res. 2013, 2, 189-191.

55. Cheng, A.; Huang, R.; Wu, J.; Chen, C. Influence of GGBS on durability and corrosion behavior of reinforced concrete. Mater. Chem. Phys. 2005, 93, 404-411. [CrossRef]

56. Ozbay, E.; Erdemir, M.; Ibrahim, H. Utilization and efficiency of ground granulated blast furnace slag on concrete properties-A review. Constr. Build. Mater. 2016, 105, 423-434. [CrossRef]

57. Guneyisi, E.; Gesoglu, M. A study on durability properties of high-performance concretes incorporating high replacement levels of slag. Mater. Struct. 2008, 41, 479-493. [CrossRef]

58. Zhang, L.; Chen, B. Hydration and Properties of Slag Cement Activated by Alkali and Sulfate. J. Mater. Civ. Eng. 2017, 29, 1-8. [CrossRef]

59. Acharya, P.K.; Patro, S.K. Effect of lime and ferrochrome ash (FA) as partial replacement of cement on strength, ultrasonic pulse velocity and permeability of concrete. Constr. Build. Mater. 2015, 94, 448-457. [CrossRef]

60. Johari, M.A.M.; Brooks, J.J.; Kabir, S.; Rivard, P. Influence of supplementary cementitious materials on engineering properties of high strength concrete. Constr. Build. Mater. 2011, 25, 2639-2648. [CrossRef]

61. Khan, A.N.; Memon, F.A.; Rizvi, S.H.; Bhanbhro, Q.; Bheel, N. Fresh and Hardened Properties of Ground Granulated Blast Furnace Slag Made Concrete. Int. J. Mod. Res. Eng. Manag. 2018, 1, 1-7. [CrossRef]

62. Chen, X.; Wang, H.; Najm, H.; Venkiteela, G.; Hencken, J. Evaluating engineering properties and environmental impact of pervious concrete with fl y ash and slag. J. Clean. Prod. 2019, 237, 117714. [CrossRef]

63. Bilim, C.; Atis, C.D.; Tanyildizi, H.; Karahan, O. Advances in Engineering Software Predicting the compressive strength of ground granulated blast furnace slag concrete using artificial neural network. Adv. Eng. Softw. 2009, 40, 334-340. [CrossRef]

64. Ozbay, E.; Lachemi, M. Compressive strength, abrasion resistance and energy absorption capacity of rubberized concretes with and without slag. Mater. Struct. 2011, 1297-1307. [CrossRef] 
65. Jang, S.; Karthick, S.; Kwon, S. Investigation on Durability Performance in Early Aged High-Performance Concrete Containing GGBFS and FA. Adv. Mater. Sci. Eng. 2017, 2017. [CrossRef]

66. Nath, P.; Sarker, P. Effect of Fly Ash on the Durability Properties of High Strength Concrete. Procedia Eng. 2011, 14, 1149-1156. [CrossRef]

67. American Coal Ash Association Coal Combustion Product (CCP) Production \& Use Survey Report [Internet]. Farmington Hills. 2012. Available online: http:/ / www.acaa-usa.org/associations/8003/files/Final2011CCPSurvey.pdf (accessed on 9 October 2020).

68. Naik, T.R.; Singh, S.S.; Hossain, M.M.; Fellow, P.; Science, A. Permeability of concrete containing large amounts of fly ash. Cem. Concr. Res. 1994, 24, 913-922. [CrossRef]

69. Lam, L.; Wong, Y.; Poon, C. Effect of fly ash and silica fume on compressive and fracture behaviors of concrete. Cem. Concr. Res. 1998, 28, 271-283. [CrossRef]

70. Bouzoubaa, N.; Lachemi, M. Self-compacting concrete incorporating high volumes of class F fly ash Preliminary results. Cem. Concr. Res. 2001, 31, 413-420. [CrossRef]

71. Atis, C.D.; Ash, F. High-Volume Fly Ash Concrete with High Strength and Low Drying Shrinkage. J. Mater. Civ. Eng. 2003, 15, 153-156. [CrossRef]

72. Han, S.; Kim, J.; Park, Y. Prediction of compressive strength of fly ash concrete by new apparent activation energy function. Cem. Concr. Res. 2003, 33, 965-971. [CrossRef]

73. Siddique, R. Performance characteristics of high-volume Class F fly ash concrete. Cem. Concr. Res. 2004, 34, 487-493. [CrossRef]

74. Dinakar, P.; Babu, K.G.; Santhanam, M. Cement \& Concrete Composites Durability properties of high volume fly ash self compacting concretes. Cem. Concr. Compos. 2008, 30, 880-886. [CrossRef]

75. Durán-herrera, A.; Juárez, C.A.; Valdez, P.; Bentz, D.P.; Ash, F. Evaluation of sustainable high-volume fly ash concretes. Cem. Concr. Compos. J. 2011, 33, 39-45. [CrossRef]

76. Çelik, B.; Özturan, T. Green Concrete Produced by Fly Ash and Silica Fume. Int. J. Eng. Sci. Appl. 2017, 1, 1-6.

77. Huang, C.; Lin, S.; Chang, C.; Chen, H. Mix proportions and mechanical properties of concrete containing very high-volume of Class F fly ash. Constr. Build. Mater. 2013, 46, 71-78. [CrossRef]

78. Ahmaruzzaman, M. A review on the utilization of fly ash. Prog. Energy Combust. Sci. 2010, 36, 327-363. [CrossRef]

79. Poon, C.S.; Lam, L.; Wong, Y.L. A study on high strength concrete prepared with large volumes of low calcium fly ash. Cem. Concr. Res. 2000, 30, 447-455. [CrossRef]

80. Kayali, O.; Ahmed, M.S. Assessment of high volume replacement fly ash concrete-Concept of performance index. Constr. Build. Mater. 2013, 39, 71-76. [CrossRef]

81. Rivera, F.; Martínez, P.; Castro, J.; Mauricio, L. Massive volume fl y-ash concrete: A more sustainable material with fl y ash replacing cement and aggregates. Cem. Concr. Compos. 2015, 63, 104-112. [CrossRef]

82. Saha, A.K. Effect of class $\mathrm{F} \mathrm{fl} \mathrm{y} \mathrm{ash} \mathrm{on} \mathrm{the} \mathrm{durability} \mathrm{properties} \mathrm{of} \mathrm{concrete.} \mathrm{Sustain.} \mathrm{Environ.} \mathrm{Res.} \mathrm{2018,} \mathrm{28,} \mathrm{25-31.} \mathrm{[CrossRef]}$

83. Shekarchi, M.; Rafiee, A.; Layssi, H. Long-term chloride diffusion in silica fume concrete in harsh marine climates. Cem. Concr. Compos. 2009, 31, 769-775. [CrossRef]

84. Strzałkowski, J.; Garbalińska, H. The Influence of Silica Fume on the Mechanical and Thermal Parameters of Portland Cement Concretes. J. Ecol. Eng. 2019, 20, 95-102. [CrossRef]

85. Hewlett, P. Lea's Chemistry of Cement and Concrete, 4th ed.; Butterworth-Heinemann: Brlington, VT, USA, 2003 ; pp. 907-1015.

86. Khedr, S.; Abou-Zeid, M. Characteristics of silica-fume concrete. J. Mater. Civ. Eng. 1995, 6, 357-375. [CrossRef]

87. Mazloom, M.; Ramezanianpour, A.; Brooks, J.J. Effect of silica fume on mechanical properties of high-strength concrete. Cem. Concr. Compos. 2004, 26, 347-357. [CrossRef]

88. Wong, H.S.; Razak, H.A. Efficiency of calcined kaolin and silica fume as cement replacement material for strength performance. Cem. Concr. Res. 2005, 35, 696-702. [CrossRef]

89. Behnood, A.; Ziari, H. Effects of silica fume addition and water to cement ratio on the properties of high-strength concrete after exposure to high temperatures. Cem. Concr. Compos. 2008, 30, 106-112. [CrossRef]

90. Amudhavalli, N.K.; Mathew, J. Effect of silica fume on strength and durability parameters of concrete. Int. J. Eng. Sci. Emerg. Technol. 2012, 3, 28-35.

91. Ding, J.; Li, Z. Effects of Metakaolin and Silica Fume on Properties of Concrete. ACI Mater. J. 2018, 99, $393-398$.

92. Bhanja, S.; Sengupta, B. Influence of silica fume on the tensile strength of concrete. Cem. Concr. Res. 2005, 35, 743-747. [CrossRef]

93. Nochaiya, T.; Wongkeo, W.; Chaipanich, A. Utilization of fly ash with silica fume and properties of Portland cement-fly ash-silica fume concrete. Fuel 2010, 89, 768-774. [CrossRef]

94. Kou, S.; Poon, C.; Agrela, F. Cement \& Concrete Composites Comparisons of natural and recycled aggregate concretes prepared with the addition of different mineral admixtures. Cem. Concr. Compos. 2011, 33, 788-795. [CrossRef]

95. Corinaldesi, V.; Moriconi, G. Influence of mineral additions on the performance of $100 \%$ recycled aggregate concrete. Constr. Build. Mater. 2009, 23, 2869-2876. [CrossRef]

96. Emhemd, A.; Al, S.; Radonjanin, V.; Malešev, M. Green recycled aggregate concrete. Constr. Build. Mater. 2013, 47, $1503-1511$. [CrossRef]

97. Blanco, F.; Garcia, M.P.; Ayala, J.; Mayoral, G.; Garcia, M.A. The effect of mechanically and chemically activated fly ashes on mortar properties. Fuel 2006, 85, 2018-2026. [CrossRef] 
98. Poon, C.S.; Kou, S.C.; Lam, L. Compressive strength, chloride diffusivity and pore structure of high performance metakaolin and silica fume concrete. Constr. Build. Mater. 2006, 20, 858-865. [CrossRef]

99. Özcan, F.; Atiş, C.D.; Karahan, O.; Uncuoğlu, E.; Tanyildizi, H. Comparison of artificial neural network and fuzzy logic models for prediction of long-term compressive strength of silica fume concrete. Adv. Eng. Softw. 2009, 40, 856-863. [CrossRef]

100. Patil, B.B.; Kumbhar, P.D. Strength and Durability Properties of High Performance Concrete incorporating High Reactivity Metakaolin. Int. J. Mod. Eng. Res. 2012, 2, 1099-1104.

101. Zhang, M.; Malhotra, V. Characteritics of a thermally activated alumina-silicate pozzolanic material and its use in concrete. Cem. Concr. Res. 1995, 25, 1713-1725. [CrossRef]

102. Vu, D.D.; Stroeven, P.; Bui, V.B. Strength and durability aspects of calcined kaolin-blended Portland cement mortar and concrete. Cem. Concr. Compos. 2001, 23, 471-478. [CrossRef]

103. Kadri, E.; Kenai, S.; Ezziane, K.; Siddique, R.; Schutter, G. De Applied Clay Science In fl uence of metakaolin and silica fume on the heat of hydration and compressive strength development of mortar. Appl. Clay Sci. 2011, 53, 704-708. [CrossRef]

104. Rovnaníková, P.; Vejmelková, E.; Pavlíková, M.; Keppert, M.; Sedlmajer, M.; Robert, C.; Ondrác, M. High performance concrete with Czech metakaolin: Experimental analysis of strength, toughness and durability characteristics. Constr. Build. Mater. 2010, 24, 1404-1411. [CrossRef]

105. Batis, G.; Pantazopoulou, P.; Tsivilis, S.; Badogiannis, E. The effect of metakaolin on the corrosion behavior of cement mortars. Cem. Concr. Compos. 2005, 27, 125-130. [CrossRef]

106. Barbhuiya, S.; Chow, P.; Memon, S. Microstructure, hydration and nanomechanical properties of concrete containing metakaolin. Constr. Build. Mater. 2015, 95, 696-702. [CrossRef]

107. Dinakar, P.; Sahoo, P.K.; Sriram, G. Effect of Metakaolin Content on the Properties of High Strength Concrete. Int. J. Concr. Struct. Mater. 2013, 7, 215-223. [CrossRef]

108. Ramezanianpour, A.A.; Jovein, H.B. Influence of metakaolin as supplementary cementing material on strength and durability of concretes. Constr. Build. Mater. 2012, 30, 470-479. [CrossRef]

109. Qian, X.; Li, Z. The relationships between stress and strain for high-performance concrete with metakaolin. Cem. Concr. Res. 2001, 31, 1607-1611. [CrossRef]

110. Lee, S.T.; Moon, H.Y.; Hooton, R.D.; Kim, J.P. Effect of solution concentrations and replacement levels of metakaolin on the resistance of mortars exposed to magnesium sulfate solutions. Cem. Concr. Res. 2005, 35, 1314-1323. [CrossRef]

111. Cassagnabère, F.; Escadeillas, G.; Mouret, M. Study of the reactivity of cement / metakaolin binders at early age for specific use in steam cured precast concrete. Constr. Build. Mater. 2009, 23, 775-784. [CrossRef]

112. Wild, S.; Khatib, J.M.; Jones, A. Relative strength, pozzolanic activity and cement hydration in superplasticised metakaolin concrete. Cem. Concr. Res. 1996, 26, 1537-1544. [CrossRef]

113. Rashad, A.M.; Sadek, D.M. An investigation on Portland cement replaced by high-volume GGBS pastes modified with micro-sized metakaolin subjected to elevated temperatures. Int. J. Sustain. Built Environ. 2017, 6, 91-101. [CrossRef]

114. Poon, C.S.; Azhar, S.; Anson, M.; Wong, Y.L. Performance of metakaolin concrete at elevated temperatures. Cem. Concr. Compos. 2003, 25, 83-89. [CrossRef]

115. Phan, L.T.; Carino, N.J. Fire performance of high strength concrete: Research needs. Adv. Technol. Struct. Eng. 2000, 1-8.

116. Siddique, R.; Kaur, D. Properties of concrete containing ground granulated blast furnace slag (GGBFS) at elevated temperatures. J. Adv. Res. 2012, 3, 45-51. [CrossRef]

117. Li, Q.; Li, Z.; Yuan, G. Effects of elevated temperatures on properties of concrete containing ground granulated blast furnace slag as cementitious material. Constr. Build. Mater. 2012, 35, 687-692. [CrossRef]

118. Nadeem, A.; Memon, S.A.; Lo, T.Y. The performance of Fly ash and Metakaolin concrete at elevated temperatures. Constr. Build. Mater. 2014, 62, 67-76. [CrossRef]

119. Li, G.; Zhao, X. Properties of concrete incorporating fly ash and ground granulated blast-furnace slag. Cem. Concr. Compos. 2003, 25, 293-299. [CrossRef]

120. McCarthy, M.J.; Dhir, R.K. Development of high volume fly ash cements for use in concrete construction. Fuel 2005, 84, 1423-1432. [CrossRef]

121. British Standard Institution. BS 1881 (part 208) Recommendations for the Determination of Initial Surface Absorption of Concrete; British Standard Institution: London, UK, 1996.

122. Hossain, K.M.A.; Lachemi, M. Strength, durability and micro-structural aspects of high performance volcanic ash concrete. Cem. Concr. Res. 2007, 37, 759-766. [CrossRef]

123. ASTM C1202. Standard Test Method for Electrical Indication of Concrete's Ability to Resist Chloride Ion Penetration; ASTM International: West Conshohocken, PA, USA, 2012; pp. 1-8. [CrossRef]

124. Kim, H.S.; Lee, S.H.; Moon, H.Y. Strength properties and durability aspects of high strength concrete using Korean metakaolin. Constr. Build. Mater. 2007, 21, 1229-1237. [CrossRef]

125. ASTM C666/C666M. Standard Test Method for Resistance of Concrete to Rapid Freezing and Thawing; ASTM International: West Conshohocken, PA, USA, 2003; Volume 3, pp. 1-6. [CrossRef]

126. Hossain, K.M.A.; Lachemi, M. Development of volcanic ash concrete: Strength, durability, and microstructural investigations. ACI Mater. J. 2006, 103, 11-17. [CrossRef] 
127. Berndt, M.L. Properties of sustainable concrete containing fly ash, slag and recycled concrete aggregate. Constr. Build. Mater. 2009, 23, 2606-2613. [CrossRef]

128. Kou, S.C.; Poon, C.S. Long-term mechanical and durability properties of recycled aggregate concrete prepared with the incorporation of fly ash. Cem. Concr. Compos. 2013, 37, 12-19. [CrossRef]

129. Faella, C.; Lima, C.; Martinelli, E.; Pepe, M.; Realfonzo, R. Mechanical and durability performance of sustainable structural concretes: An experimental study. Cem. Concr. Compos. 2016, 71, 85-96. [CrossRef]

130. Sabet, F.A.; Libre, N.A.; Shekarchi, M. Mechanical and durability properties of self consolidating high performance concrete incorporating natural zeolite, silica fume and fly ash. Constr. Build. Mater. 2013, 44, 175-184. [CrossRef]

131. Chousidis, N.; Rakanta, E.; Ioannou, I.; Batis, G. Mechanical properties and durability performance of reinforced concrete containing fly ash. Constr. Build. Mater. 2015, 101, 810-817. [CrossRef]

132. Singh, L.P.; Ali, D.; Tyagi, I.; Sharma, U.; Singh, R.; Hou, P. Durability studies of nano-engineered fly ash concrete. Constr. Build. Mater. 2019, 194, 205-215. [CrossRef]

133. ASTM C1012/C1012M-15 Standard Test Method for Length Change of Hydraulic-Cement Mortars Exposed to a Sulfate Solution; ASTM Int.: West Conshohocken, PA, USA, 2015; Volume 11, pp. 5-9. [CrossRef]

134. CPC-18 Measurement of hardened concrete carbonation depth. Mater. Struct. 1988, 21, 453-455. [CrossRef]

135. Wang, D.; Zhou, X.; Meng, Y.; Chen, Z. Durability of concrete containing fly ash and silica fume against combined freezing-thawing and sulfate attack. Constr. Build. Mater. 2017, 147, 398-406. [CrossRef]

136. Uysal, M.; Akyuncu, V. Durability performance of concrete incorporating Class F and Class C fly ashes. Constr. Build. Mater. 2012, 34, 170-178. [CrossRef]

137. Yoo, S.W.; Ryu, G.S.; Choo, J.F. Evaluation of the effects of high-volume fly ash on the flexural behavior of reinforced concrete beams. Constr. Build. Mater. 2015, 93, 1132-1144. [CrossRef]

138. Fuzail Hashmi, A.; Shariq, M.; Baqi, A. Flexural performance of high volume fly ash reinforced concrete beams and slabs. Structures 2020, 25, 868-880. [CrossRef]

139. Sangeetha, S.P.; Joanna, P.S. Open Access Flexural Behaviour of Reinforced Concrete Beams with Partial Replacement of GGBS. Am. J. Eng. Res. 2014, 3, 119-127.

140. Arezoumandi, M.; Volz, J.S. Effect of fly ash replacement level on the shear strength of high-volume fly ash concrete beams. J. Clean. Prod. 2013, 59, 120-130. [CrossRef]

141. Sunayana, S.; Barai, S.V. Shear behavior of fly-ash-incorporated recycled aggregate concrete beams. ACI Struct. J. 2020, 117, 289-303. [CrossRef]

142. Alghazali, H.H.; Myers, J.J. Shear behavior of full-scale high volume fly ash-self consolidating concrete (HVFA-SCC) beams. Constr. Build. Mater. 2017, 157, 161-171. [CrossRef]

143. Bertolini, L. Steel corrosion and service life of reinforced concrete structures. Struct. Infrastruct. Eng. 2008, 4, 123-137. [CrossRef]

144. Topçu, I.B.; Boĝa, A.R. Effect of ground granulate blast-furnace slag on corrosion performance of steel embedded in concrete. Mater. Des. 2010, 31, 3358-3365. [CrossRef]

145. Barnett, S.J.; Soutsos, M.N.; Millard, S.G.; Bungey, J.H. Strength development of mortars containing ground granulated blastfurnace slag: Effect of curing temperature and determination of apparent activation energies. Cem. Concr. Res. 2006, 36, 434-440. [CrossRef]

146. Chidiac, S.E.; Panesar, D.K. Evolution of mechanical properties of concrete containing ground granulated blast furnace slag and effects on the scaling resistance test at 28 days. Cem. Concr. Compos. 2008, 30, 63-71. [CrossRef]

147. Chen, Z.; Yang, Y.; Yao, Y. Quasi-static and dynamic compressive mechanical properties of engineered cementitious composite incorporating ground granulated blast furnace slag. Mater. Des. 2013, 44, 500-508. [CrossRef]

148. Dinakar, P.; Sethy, K.P.; Sahoo, U.C. Design of self-compacting concrete with ground granulated blast furnace slag. Mater. Des. 2013, 43, 161-169. [CrossRef]

149. Tsai, C.J.; Huang, R.; Lin, W.T.; Wang, H.N. Mechanical and cementitious characteristics of ground granulated blast furnace slag and basic oxygen furnace slag blended mortar. Mater. Des. 2014, 60, 267-273. [CrossRef]

150. Indian Standard. IS 456 2000: Plain and Reinforced Concrete. Code of Practice (4th Revision); Indian Standard: Mirzapur, India, 2000.

151. Hawileh, R.A.; Abdalla, J.A.; Fardmanesh, F.; Shahsana, P.; Khalili, A. Performance of reinforced concrete beams cast with different percentages of GGBS replacement to cement. Arch. Civ. Mech. Eng. 2017, 17, 511-519. [CrossRef]

152. Rao, P.; Mohan, S.; Sekar, S. Shear resistance of high volume fly ash reinforced concrete beams without web reinforcement. Int. J. Civ. Struct. Eng. 2013, 1, 986-993.

153. Arezoumandi, M.; Volz, J.S.; Myers, J.J. Shear behavior of high-volume fly ash concrete versus conventional concrete. J. Mater. Civ. Eng. 2013, 25, 1506-1513. [CrossRef]

154. Li, X. Recycling and reuse of waste concrete in China: Part II. Structural behaviour of recycled aggregate concrete and engineering applications. Resour. Conserv. Recycl. 2009, 53, 107-112. [CrossRef]

155. Hoffmann, C.; Schubert, S.; Leemann, A.; Motavalli, M. Recycled concrete and mixed rubble as aggregates: Influence of variations in composition on the concrete properties and their use as structural material. Constr. Build. Mater. 2012, 35, 701-709. [CrossRef]

156. Ryu, J.S. Improvement on strength and impermeability of recycled concrete. J. Mater. Sci. Lett. 2002, 21, 1565-1567. [CrossRef]

157. Savaş, E.; Dawson, A.R.; Howard, T.N. Influence of the micro- and nanoscale local mechanical properties of the interfacial transition zone on impact behavior of concrete made with different aggregates. Cem. Concr. Res. 2012, 42, 447-458. 
158. Tokyay, M.; Tahir, C. Assessing the ITZ microcracking via scanning electron microscope and its effect on the failure behavior of concrete. Cem. Concr. Res. 2005, 35, 358-363. [CrossRef]

159. Bao, J.; Li, S.; Zhang, P.; Ding, X.; Xue, S.; Cui, Y.; Zhao, T. Influence of the incorporation of recycled coarse aggregate on water absorption and chloride penetration into concrete (a) NCAs (b) RCAs. Constr. Build. Mater. 2020, 239, 117845. [CrossRef]

160. Poon, C.S.; Shui, Z.H.; Lam, L. Effect of microstructure of ITZ on compressive strength of concrete prepared with recycled aggregates. Constr. Build. Mater. 2004, 18, 461-468. [CrossRef]

161. Younis, K.H. Feasibility of Using Nanoparticles of $\mathrm{SiO}_{2}$ to Improve the Performance of Recycled Aggregate Concrete. Adv. Mater. Sci. Eng. 2018, 2018, 3-5. [CrossRef]

162. Li, W.; Xiao, J.; Sun, Z.; Kawashima, S.; Shah, S.P. Interfacial transition zones in recycled aggregate concrete with different mixing approaches. Constr. Build. Mater. 2012, 35, 1045-1055. [CrossRef]

163. Otsuki, N.; Asce, M.; Miyazato, S.; Yodsudjai, W. Influence of Recycled Aggregate on Interfacial Transition Zone, Strength, Chloride Penetration and Carbonation of Concrete. J. Mater. Civ. Eng. 2003, 15, 443-451. [CrossRef]

164. Bai, G.; Zhu, C.; Liu, C.; Liu, B. An evaluation of the recycled aggregate characteristics and the recycled aggregate concrete mechanical properties. Constr. Build. Mater. 2020, 240, 117978. [CrossRef]

165. Katz, A. Treatments for the Improvement of Recycled Aggregate. J. Mater. Civ. Eng. 2004, 16, 597-603. [CrossRef]

166. Han, B.; Yun, H.; Chung, S. Shear Capacity of Reinforced Concrete Beams Made with Recycled Aggregate. ACI Symp. Publ. 2001, 200, 503-516.

167. Al mahmoud, F.; Boissiere, R.; Mercier, C.; Khelil, A. Shear behavior of reinforced concrete beams made from recycled coarse and fine aggregates. Structures 2020, 25, 660-669. [CrossRef]

168. González-Fonteboa, B.; Martínez-Abella, F. Shear strength of recycled concrete beams. Constr. Build. Mater. 2007, 21, 887-893. [CrossRef]

169. Etxeberria, M.; Marí, A.R.; Vázquez, E. Recycled aggregate concrete as structural material. Mater. Struct. Constr. 2007, 40, 529-541. [CrossRef]

170. Fathifazl, G.; Razaqpur, A.G.; Burkan Isgor, O.; Abbas, A.; Fournier, B.; Foo, S. Shear capacity evaluation of steel reinforced recycled concrete (RRC) beams. Eng. Struct. 2011, 33, 1025-1033. [CrossRef]

171. Knaack, A.M.; Kurama, Y.C. Behavior of reinforced concrete beams with recycled concrete coarse aggregates. J. Struct. Eng. 2015, 141. [CrossRef]

172. Arezoumandi, M.; Smith, A.; Volz, J.S.; Khayat, K.H. An experimental study on shear strength of reinforced concrete beams with 100\% recycled concrete aggregate. Constr. Build. Mater. 2014, 53, 612-620. [CrossRef]

173. AASHTO LRFD. American Association of State Highway and Transportation Officials. Bridge Design Specifications, 2nd ed.; AASHTO LRFD: Washington, DC, USA, 2012; ISBN 9781560515234.

174. American Concrete Institute ACI Committee. Building Code Requirements for Structural Concrete ACI 318-19 and Commentary 318R-19; American Concrete Institute ACI Committee: Farmington Hills, MI, USA, 2019; ISBN 9781641950565.

175. CSA Group. Design of Concrete Structures (CSA A23. 3-14); Canadian Standards Association: Toronto, ON, Canada, 2014.

176. JSCE (Japan Society of Civil Engineers). Recommendation for Design and Construction of Concrete Structures Using Continuous Fiber Reinforcing Materials; JSCE: Tokyo, Japan, 1997.

177. Xu, S.; Zhang, X.; Reinhardt, H.W. Shear capacity prediction of reinforced concrete beams without stirrups using fracture mechanics approach. ACI Struct. J. 2012, 109, 705-713. [CrossRef]

178. Sadati, S.; Arezoumandi, M.; Khayat, K.H.; Volz, J.S. Shear performance of reinforced concrete beams incorporating recycled concrete aggregate and high-volume fly ash. J. Clean. Prod. 2016, 115, 284-293. [CrossRef]

179. Ji, S.K.; Lee, W.S.; Do Yun, H. Shear Strength of Reinforced Concrete Beams with Recycled Aggregates; Taylor \& Francis Group: London, UK, 2008; ISBN 9780415475358.

180. Arezoumandi, M.; Volz, J.; Myers, J. Effect of high-volume fly ash on shear strength of concrete beams. Transp. Res. Rec. 2013, 1-9. [CrossRef]

181. Arezoumandi, M.; Volz, J.S.; Ortega, C.A.; Myers, J.J. Shear behavior of high-volume fly ash concrete versus conventional concrete: Experimental study. J. Struct. Eng. 2015, 141, 1-11. [CrossRef]

182. Lisantono, A.; Wigroho, H.Y.; Purba, R.A. Shear Behavior of High-volume Fly Ash Concrete as Replacement of Portland Cement in RC Beam. Procedia Eng. 2017, 171, 80-87. [CrossRef] 